\title{
50. OLIGOCENE AND OTHER TERTIARY BENTHIC FORAMINIFERS FROM A DEPTH TRAVERSE DOWN WALVIS RIDGE, DEEP SEA DRILLING PROJECT LEG 74, SOUTHEAST ATLANTIC 12
}

\author{
Anne Boersma, Box 404, RRI, Stony Point, New York
}

\begin{abstract}
Analyses were made of benthic foraminifers in the $>149 \mu \mathrm{m}$ fractions of sediments from five depth-graded sites, $525,526,527,528$, and 529, down the flanks of the Walvis Ridge into the southern Angola Basin. Faunal contamination, in part attributed to the coring process, is prevalent through the Miocene at Sites 525, 526, and 528, where extremely large and some modern specimens are emplaced in the faunas. Oligocene-age taxa from Sites 526 and 529 were studied in the greatest detail, in order to allow comparison of faunas from deep water and intermediate water depths through this time.

In the Paleocene, Site 525 (1400 m paleodepth) contained at least 11 species with "Midway" affinities; the adjacent deep-water Site 527 (3200 paleodepth) contained typical Paleocene deep-water taxa, at least 10 of which did not range up into the intermediate water depths at Site 525. The Paleocene/Eocene boundary is indicated by the extinction of $G a$ velinella beccariformis and the first abundant appearance of Tappanina selmensis at all paleodepths. Diachrony between these events increases at greater water depths.

Little Eocene-age sediment was well preserved, so faunas were not analyzed except across the Eocene/Oligocene boundary, which was represented by mixing and an erosional hiatus in Hole $526 \mathrm{~A}$ (near $800 \mathrm{~m}$ paleodepth) and short dissolution intervals at Site 529 (near $2800 \mathrm{~m}$ paleodepth). Taxonomic overturn across the boundary at these sites is considered ecologically controlled, not evolutionary.

Characteristic Oligocene faunas distinguish Site 526, of intermediate water depth, from deep-water Site 529; taxa restricted to the shallower site include Uvigerina semivestita, Rectuvigerina postprandia, U. spinulosa, Bolivina tectiformis, Nodogenerina sp., Palmula sp., and Cibicides lobulatus. Species richness and the number of benthic specimens/ $0.5 \mathrm{~g}$ sediment are both much greater at the intermediate-depth site.

Miocene faunas at Sites 525 and 526 are depleted in benthic foraminifers; this depletion is particularly evident at Site 526, where the benthics were very abundant in the Oligocene. Faunas at the two sites (through $1000-2500 \mathrm{~m}$ paleodepth) are markedly similar, although first and last appearances are diachronous through depth. Several originations in Zones N11-N13 are, however, synchronous and may represent the effects of the mid-Miocene glaciation.

Comparison of Pliocene faunas at deep-water Site 525 and at Site 527 (near $4000 \mathrm{~m}$ paleodepth) demonstrates higher benthic abundance and diversity at the shallower site. The major change in faunas occurs in Pliocene zones Pl5-P16, where faunas again are homogeneous through depth and Nuttallides umbonifera, a bottom-water index, occurs in nearly equal abundances at all sites.
\end{abstract}

\section{INTRODUCTION}

On Leg 74, five sites were drilled along a traverse from the Walvis Ridge crest into the southern Angola Basin to the north. Site locations are shown in Figure 1. The sections recovered at Sites 525, 527, 528, and 529 range from basal Paleocene through Pleistocene; at Site 526, sediments of the upper Paleocene through Pleistocene were recovered. (See Fig. 2.)

From the Oligocene of Sites 526 and 529, benthic foraminifers from the $>149 \mu \mathrm{m}$ fraction of sediments in core catchers and one additional sample per core were analyzed. Through the Tertiary section at other sites, one sample per core was analyzed. Benthic foraminifers from $0.5 \mathrm{~g}$ of sediment were picked, identified, and counted for the Oligocene at Sites 526 and 529, for one core from Miocene sediments at Site 525, and for the Pliocene at Sites 525 and 527. Specific "diversity" is a simple estimate of species richness.

\footnotetext{
${ }^{1}$ Hay, W. W., Sibuet, J.-C., et al., Init. Repts. DSDP, 75: Washington (U.S. Govt. Printing Office).

2 Moore, T. C., Jr., Rabinowitz, P. D., et al., Init. Repts. DSDP, 74: Washington (U.S. Govt. Printing Office).
}

\section{BIOSTRATIGRAPHY OF BENTHIC FORAMINIFERAL FAUNAS}

\section{Paleocene}

Incomplete Paleocene sections were recovered from Sites 525, 527, 528, and 529. Hole 526C bottomed in shallow-water carbonate sands and limestone which, according to nannofossil data (Manivit, in press), may have been late Paleocene in age. These sediments contain only few abraded larger foraminifers which are not described in this study.

The Paleogene sections were subdivided according to the biostratigraphic zonation of Hardenbol and Berggren (1978). The most complete section was found at Site 527, which includes small thicknesses of all Paleogene zones. At the other sites, Zones P1d and P2 are missing; Zone P3a is only found mixed into Zone P1 levels at Site 528. Site 529 (and to a lesser degree, Site 528) contains several slumps in the mid and upper Paleocene.

Benthic foraminifers from the Paleocene of Holes 525A and 527 are listed in Figures 3 and 4. At both sites the preservation is moderate to good, but it is generally better at Site 527. Although the section at Site 525 is less 


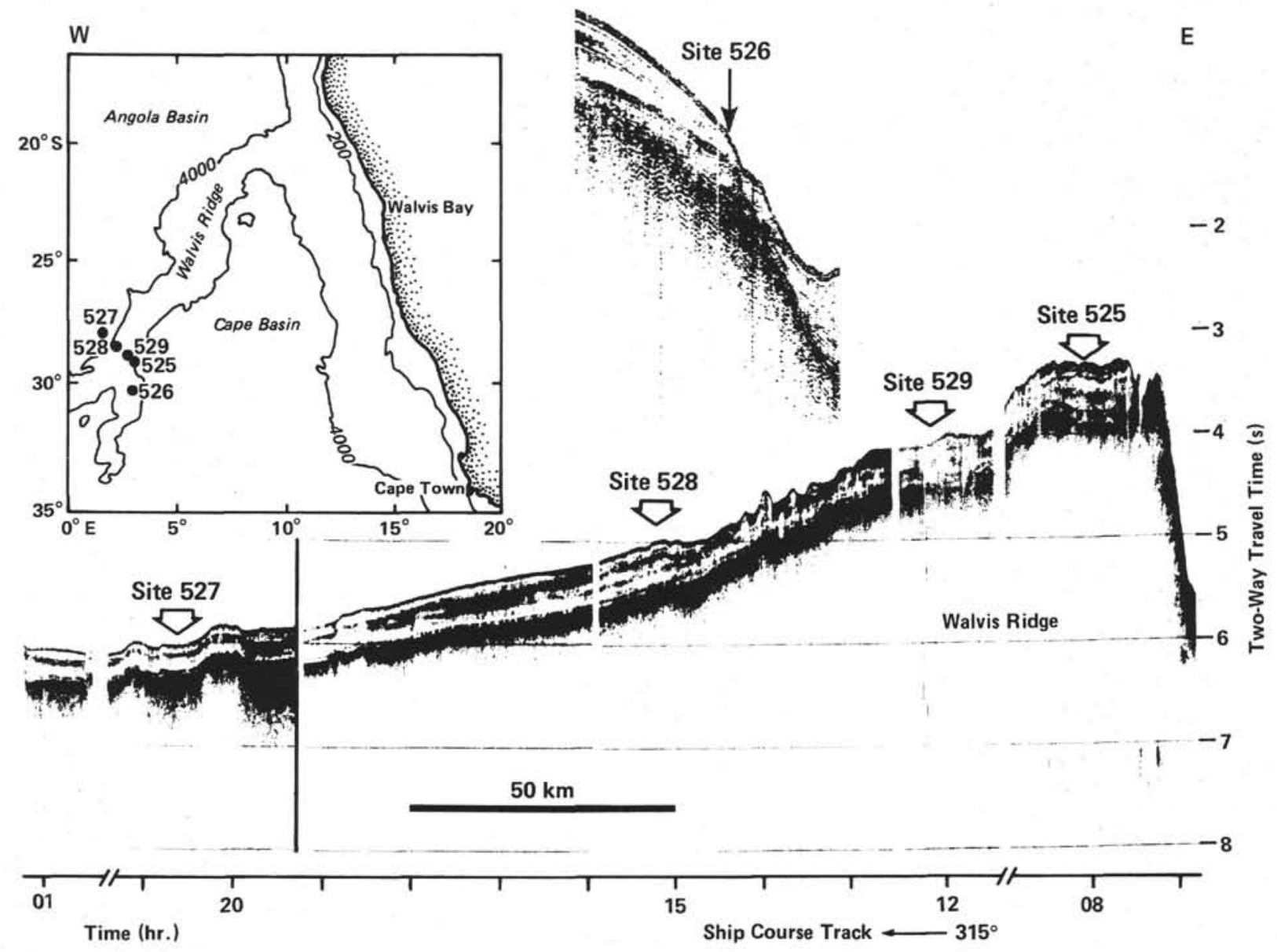

Figure 1. Location map of Leg 74 site.

complete, it contains longer sections of the zones represented. Site 527 was drilled at significantly greater depths than was Site 525. Paleodepth estimates derived from the backtrack curve in Figure 5 indicate that in the $\mathrm{Pa}$ leocene Site 525 lay close to $1400 \mathrm{~m}$ depth, and Site 527 near $3200 \mathrm{~m}$ depth.

Taxa present in the shallower Hole 525A but not at Site 527 include Lagena sulcata, Bolivina crenulata, Dentalina naheolensis, Nodosaria latejugata, Frondicularia sp., Vulvulina spinosa, Robulus turbinatus, Gavelinella danica, Allomorphina paleocenica, Globulina gibba, and Coryphostoma midwayensis. Most of these species were identified originally by Cushman (1951) from shallow, onshore Midway sections of the Gulf Coast of the United States.

The species restricted to Site 527 in the Paleocene are Abyssamina poagi, Clinapertina inflata, Cibicidoides cf. tuxpamensis, Gavelinella hyphalus, Gaudryina spp., Spiroplectammina haeringensis, $N$. limbata, Ammobaculites sp., $D$. eocenica, and $D$. nasuta.

Most of the appearances or disappearances at these sites are considered to reflect varying ecologic conditions. Species which first appear synchronously at both sites may indicate first appearances: they are Bolivinopsis $\mathrm{cu}$ bensis and Bulimina quadrata in Zone P3b, and Tappanina selmensis and Globocassidulina subglobosa in Zone P6.

\section{Paleocene/Eocene Boundary}

Three apparently complete Paleocene/Eocene boundary sequences were recovered on Leg 74, at the shallower Site 525 and the two deeper Sites 527 and 528 . The boundary was initially located by planktonic foraminifers (Fig. 6).

The major evolutionary change in Tertiary benthic foraminifers occurs at the Paleocene/Eocene boundary and is signalled worldwide by (inter alia) the extinction of Gavelinella beccariformis, the ecologic reappearance and entrance into deeper marine sections of Tappanina selmensis, the appearance of common Eocene buliminids, and a decrease in size of most benthic species across the boundary (R. C. Tjalsma, personal communication, 1982). These events were determined in detail at the three Leg 74 sites and compared with the placement of the boundary based on planktonic foraminifers. As shown in Figure 6, the exact timing and nature of these events may be depth-related, as follows:

1) At all sites, $T$. selmensis appears before $G$. beccariformis becomes extinct; however, the offset between the two events is significantly less at the shallower Hole 525A;

2) At all sites the decrease in size of the benthic individuals occurs just following an excursion in carbon isotopes (Shackleton and Hall, in press); there is a signifi- 
cant offset between the carbon isotope excursion and the evolutionary events among the benthic foraminifers at Sites 525 and 527, but changes in the foraminifers bracket both the boundary and the carbon isotope excursion at Site 528.

\section{Eocene-Oligocene}

Incomplete Eocene sections were recovered at all sites. Because of the small, discontinuous segments of material recovered from this time period, the benthic foraminifers were not studied in detail.

A somewhat mixed, but relatively complete Eocene/ Oligocene boundary sequence was found at Site 529 . Marking the boundary were the disappearance of $\mathrm{Nut}$ tallides truempyi, the appearance of $N$. umbonifera, a dissolution horizon and a reduction in benthic abundance, and a short-lived influx of miliolids just above the boundary and above the dissolution horizon.

A nearly complete Oligocene sequence was recovered at Site 529; benthic species through this interval are listed in Figure 7. Sediments throughout the sequence are well preserved, with the exception of the dissolution horizon across the boundary. Some mixing of Eocene into Oligocene was observed at discrete intervals in the lower Oligocene. A long, but less complete section ranging from Zones P19/20 through Zone P22 was drilled in Hole 526A. As shown in Figure 5, this site lay near $800 \mathrm{~m}$ through the course of the Oligocene and thus was in a markedly different watermass from Site 529. Species at Site 526 are listed in Figure 8.

Most appearances or disappearances of species are diachronous between the two sites and are considered ecologically controlled, except for (1) the appearance of Uvigerina pygmaea at the base of Zone P22; and (2) the appearance of Rectuvigerina postprandia at the base of Zone P20.

\section{Miocene-Pliocene}

Long, but incomplete Miocene sections were recovered at all but the deepest Site 527, which apparently lay below the foraminiferal CCD during this epoch. The sediments are uniformly well preserved; short hiatuses and poorer preservation occur in the middle/lower Miocene boundary interval. Unfortunately, in the top sections of many cores, particularly at the HPC sites, coarse, sizesorted Miocene-Pliocene sediments were emplaced by the coring process. This downhole contamination has rendered biostratigraphy more difficult and has confused interpretation of the benthic faunas.

Miocene benthic species are listed in Table 1 and Figure 9 for the two shallowest sites, 525 and 526. As shown in Figure 5, at this time Site 525 had a depth near its present depth of $2450 \mathrm{~m}$; Site 526 was located at 900-1000 m paleodepth.

Faunas at Site 526 contain many species deriving from the Oligocene, such as Cibicides lobatulus, Textularia mexicana, and Rectuvigerina postprandia, which recur episodically through the Miocene. The major time of faunal turnover is Zones N12-13, when several species, including Sphaeroidina bulloides, disappear and eight new species first appear in the faunas. These include the characteristic Pliocene species Pleurostomella alternans, Bulimina mexicana striata, and Stilostomella lepidula.

At Site 525 Miocene benthic foraminifers are not common in any sample, and only abbreviated lists were compiled of the several taxa which did occur in a $10 \mathrm{~cm}^{3}$ sample. Most species which appear by Zone N14 range into and through the Pliocene (see Table 1).

\section{PALEOECOLOGY}

Several more detailed paleoecologic studies were undertaken in order to examine

1) the relation of benthic faunas to the depths along the depth traverse and hence to water masses at the several different bottom depths;

2) the utility of benthic faunas for predicting the depth of a site in the past;

3) the relation between benthic faunas and burrowing cycles and sediment disturbance; and

4) the effect of dissolution on benthic faunas.

\section{Faunal Change with Depth}

Variation in benthic faunas with depth through the early Paleocene was examined qualitatively by making a census of the most common three or four species or genera at Sites 525,528 , and 527 , which range in paleodepths (Fig. 5) from approximately $1400-3500 \mathrm{~m}$ in the early Paleocene to $2200-4200 \mathrm{~m}$ by the late Eocene. These faunas and their variability through time are shown in Table 2. Throughout this time the shallower Site 525 was dominated by Nuttalides truempyi, Gavelinella beccariformis, and/or Osangularia mexicana. Nuttallides and pleurostomellids were typical of the intermediate Site 528, whereas at the deepest site Nuttallides, Aragonia spp., and the stilostomellids are the most common components of the faunas.

Detailed analyses of the Oligocene faunas at Site 526, at a paleodepth near $600 \mathrm{~m}$, and at Site 529, lying closer to $2800 \mathrm{~m}$, included counts of all species in $0.5 \mathrm{~g}$ of sediment of the $>64 \mu \mathrm{m}$ fraction. Comparative samples from Sites 525 and 363 (Leg 40) were also counted and the results are shown in Figures 10-12.

Over 41 species were identified from the Oligocene of Site 526 in sediments of Zones P20-P22 age. Species diversity is lower at the base of Zone P20, increases through Zones P20 and P21, then decreases again slightly near the top of Zone P22. The Benthic Number (the number of benthic specimens in $0.5 \mathrm{~g}$ of sediment) is very high at this site, averaging near 400 specimens (Fig. 10). The percentage of rectilinear benthic specimens is higher in Zone P20 and decreases gradually through the course of the upper Oligocene.

In Zone P20 at Site 526 (Fig. 11) faunas contain large proportions of uvigerinids and stilostomellids, and slightly fewer buliminids. By Zone P21b the faunal content changes: Cibicides, Robulus, and the agglutinated foraminifers increase in import so that they occur in nearly equal amounts with Stilostomella spp. Uvigerinids remain the most abundant forms. By the end of the Oligocene stilostomellids and cibicidids dominate the faunas along with significant numbers of agglutinants. 


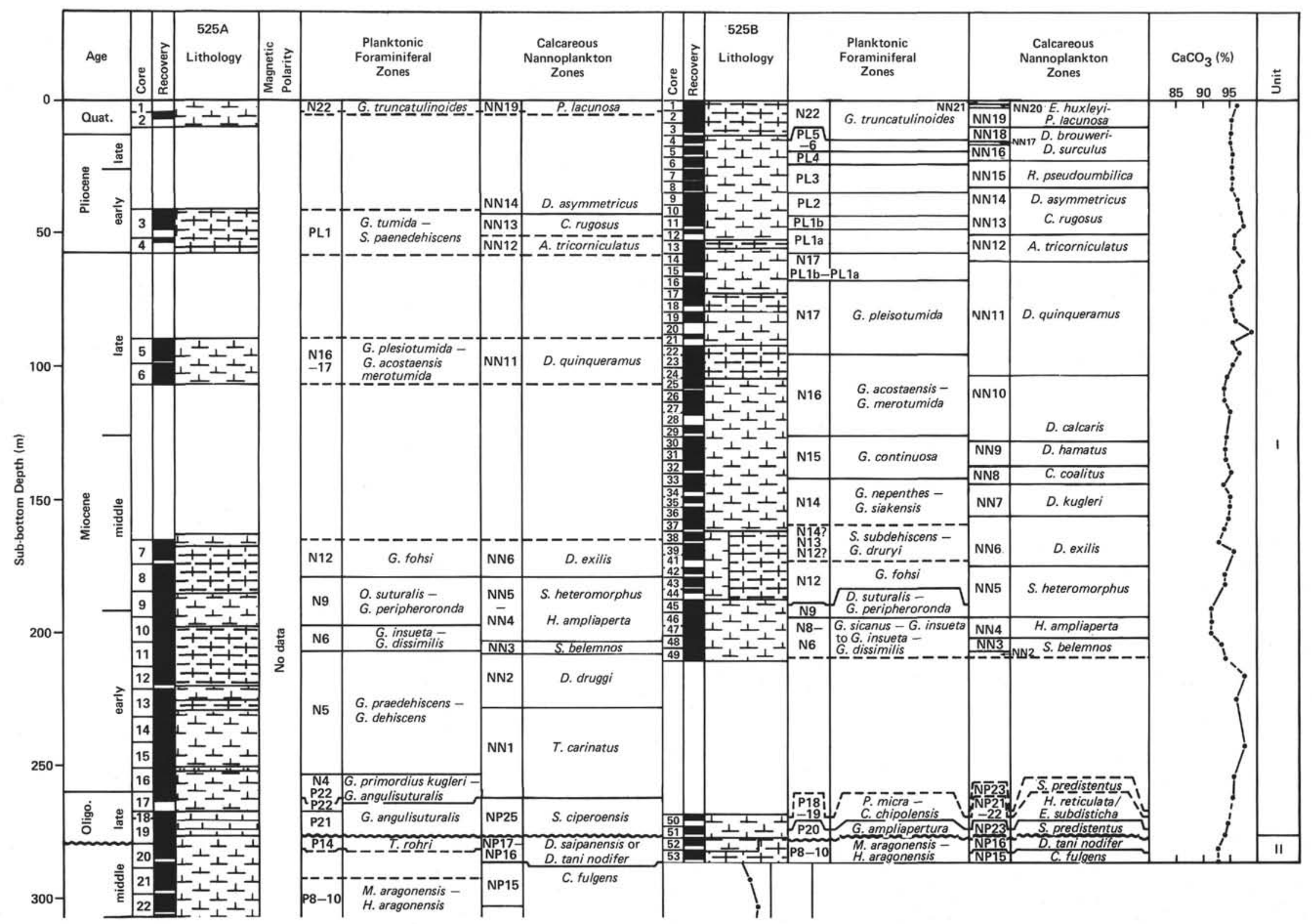




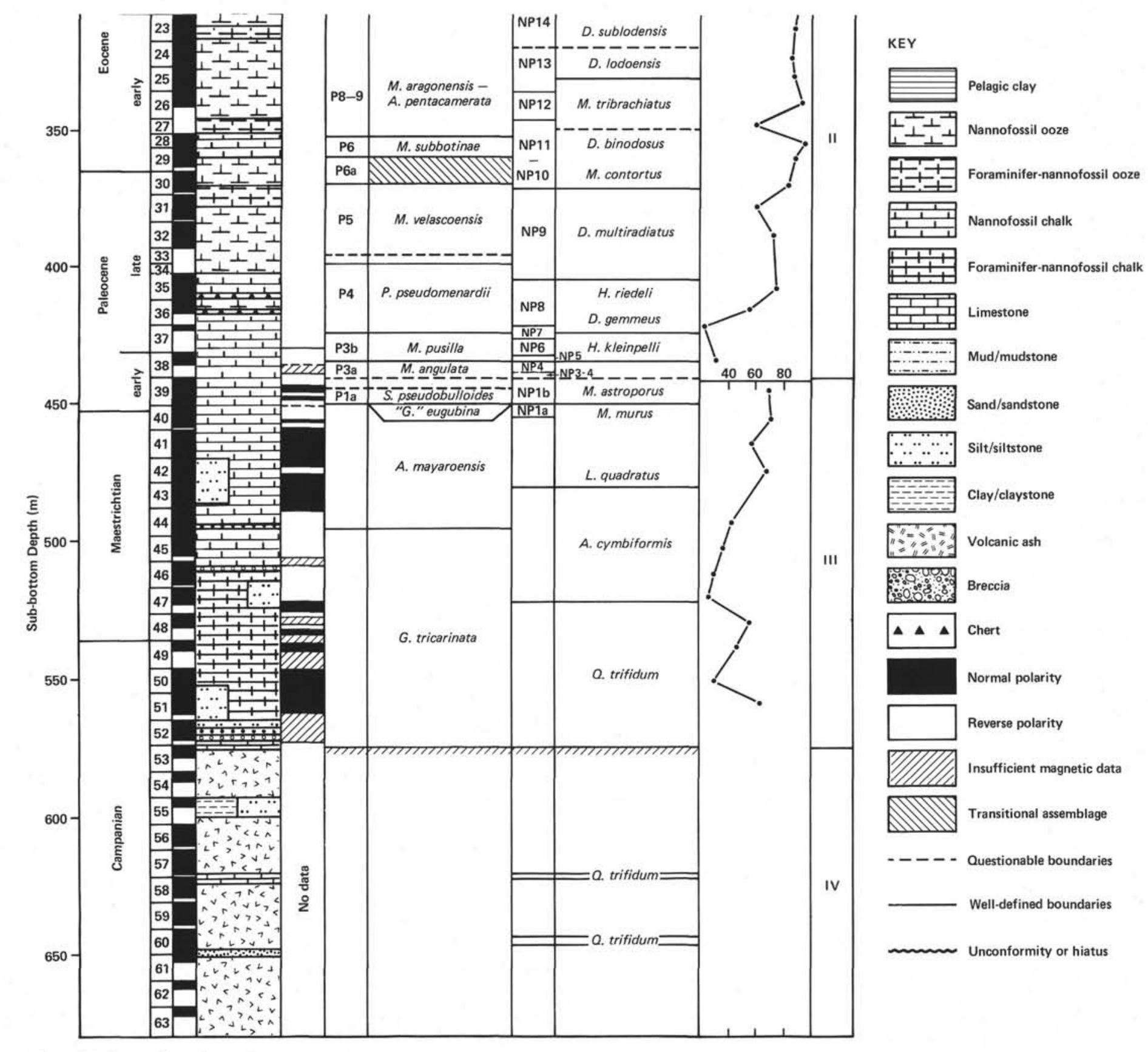




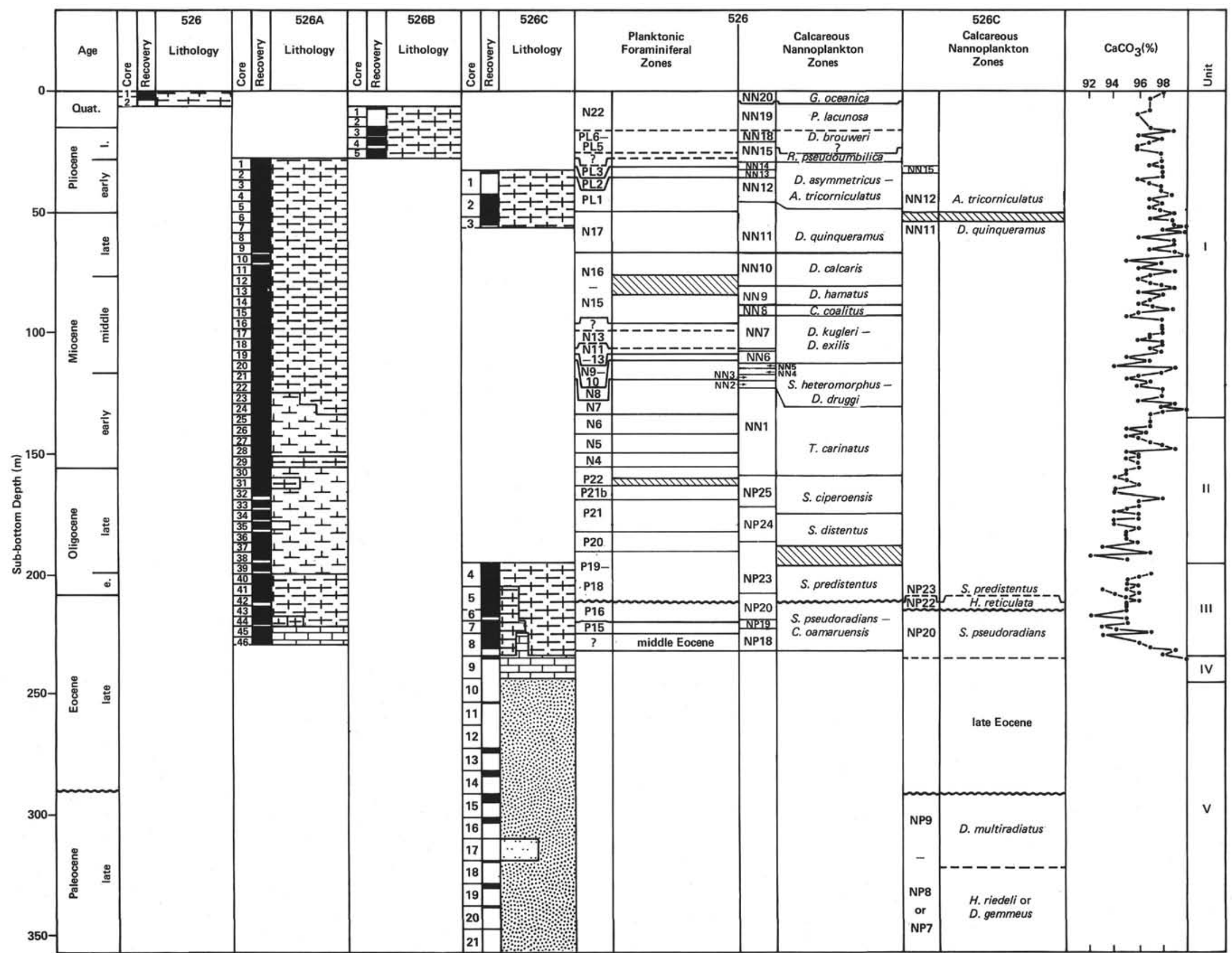




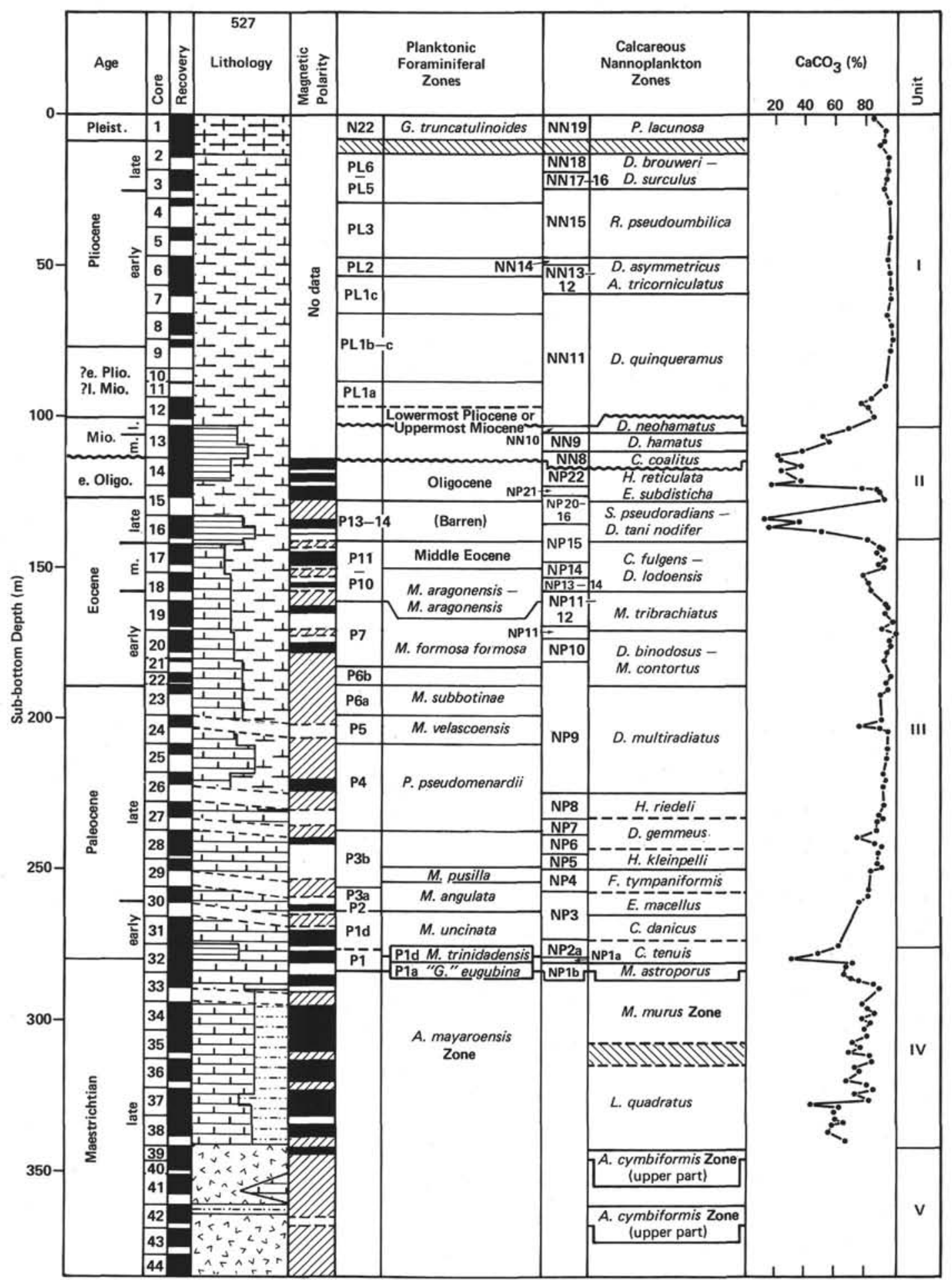

Figure 2. (Continued). 


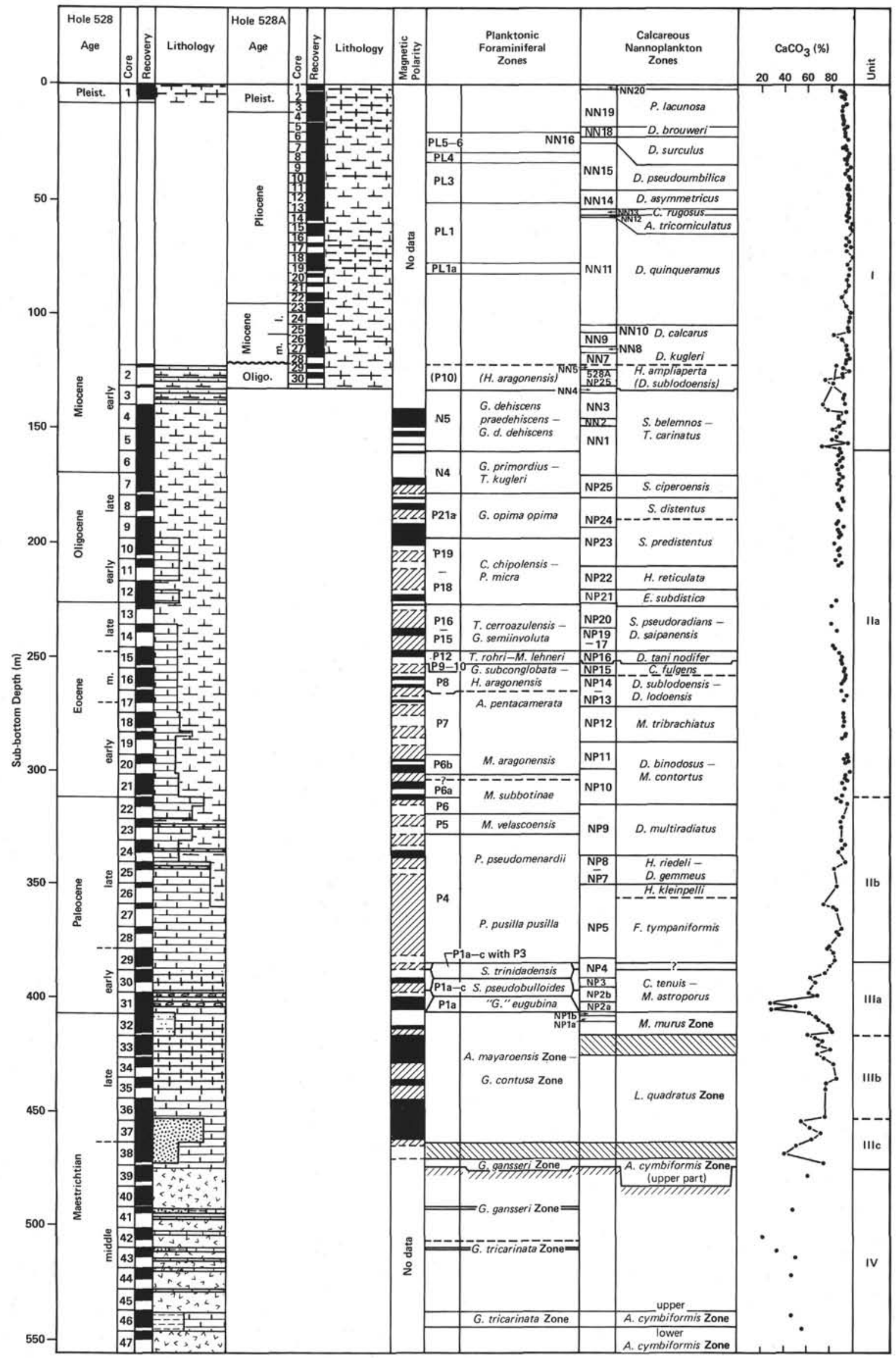

Figure 2. (Continued). 


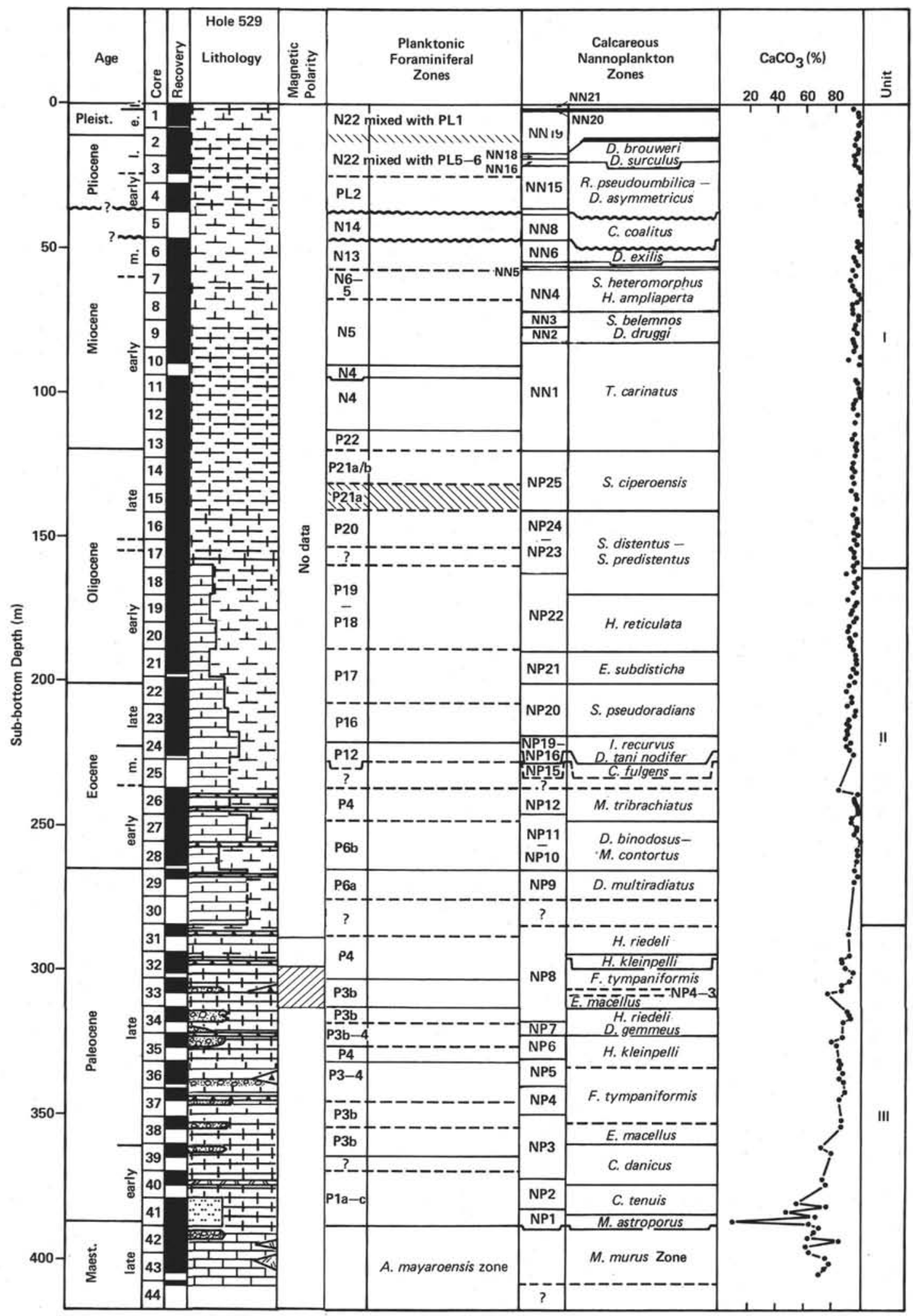

Figure 2. (Continued). 


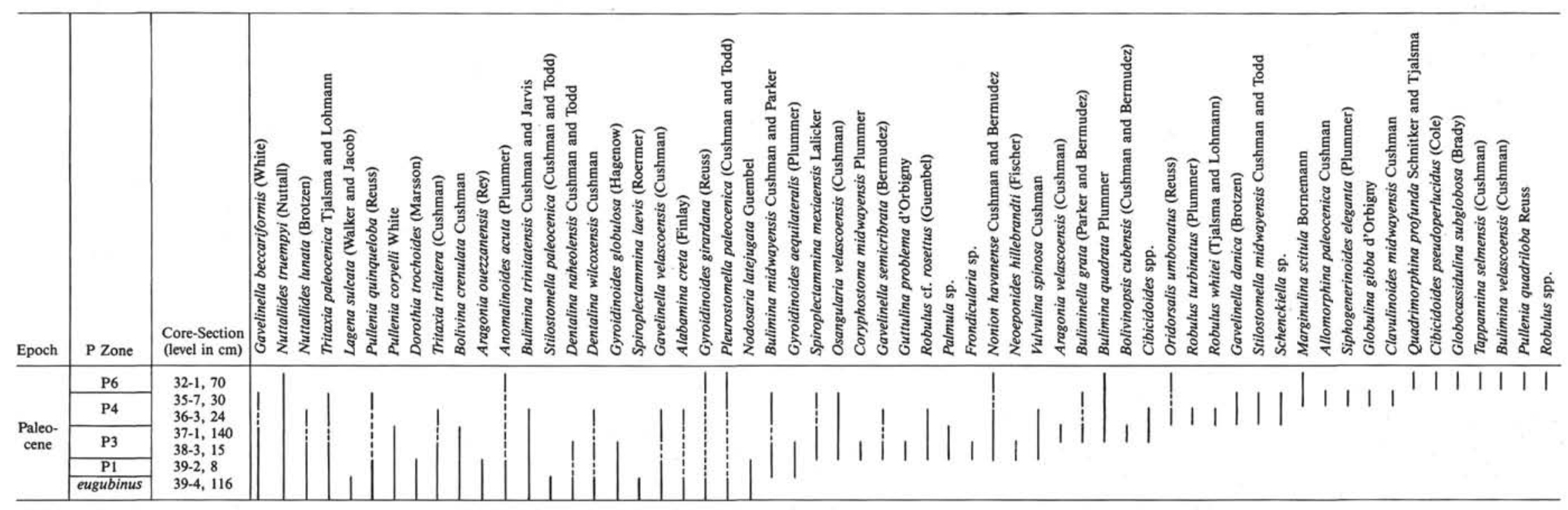

Figure 3. Stratigraphic ranges of most common benthic foraminifers through the Paleocene of Hole 525A. Samples are zoned according to the timescale and zonation of Hardenbol and Berggren (1978).

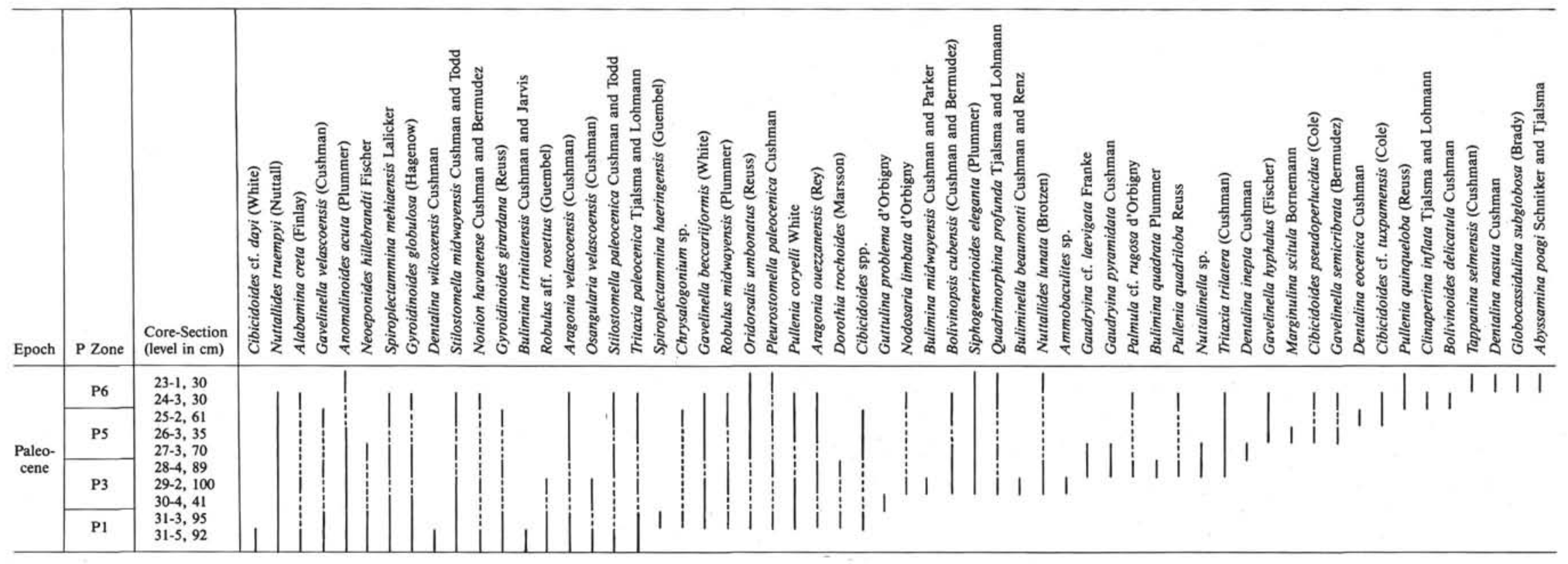

Figure 4. Stratigraphic ranges of most common benthic foraminifers through the Paleocene at Site 527. Samples are zoned according to the zonation of Hardenbol and Berggren (1978). 


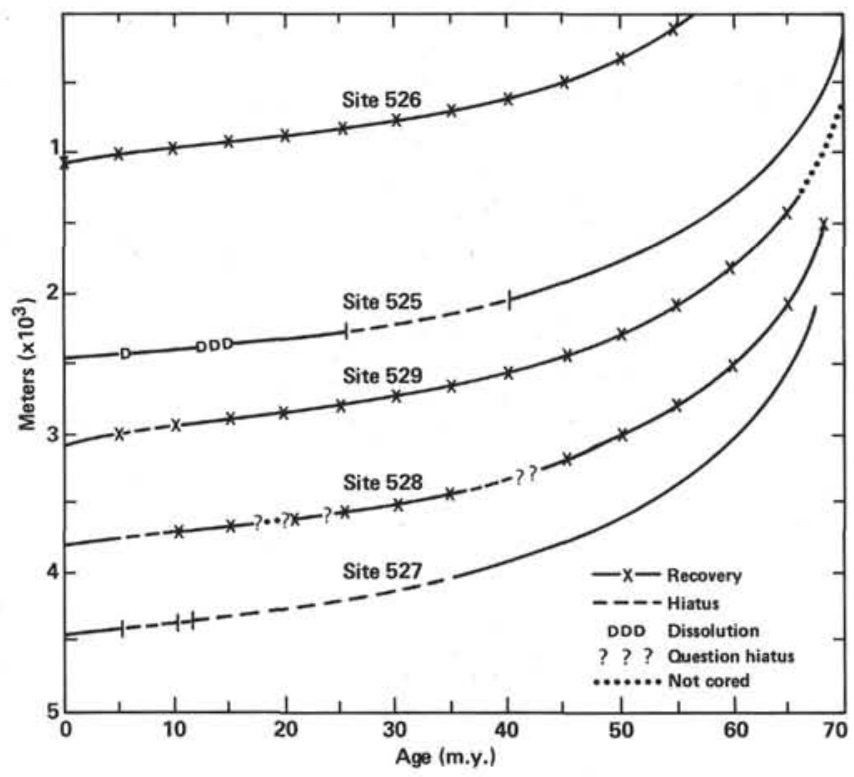

Figure 5. Depth versus age, crustal cooling and subsidence curves for the Leg 74 sites compiled by T. Moore. Ages (in m.y.) are derived from the timescale of Hardenbol and Berggren (1978) and Berggren (1972).

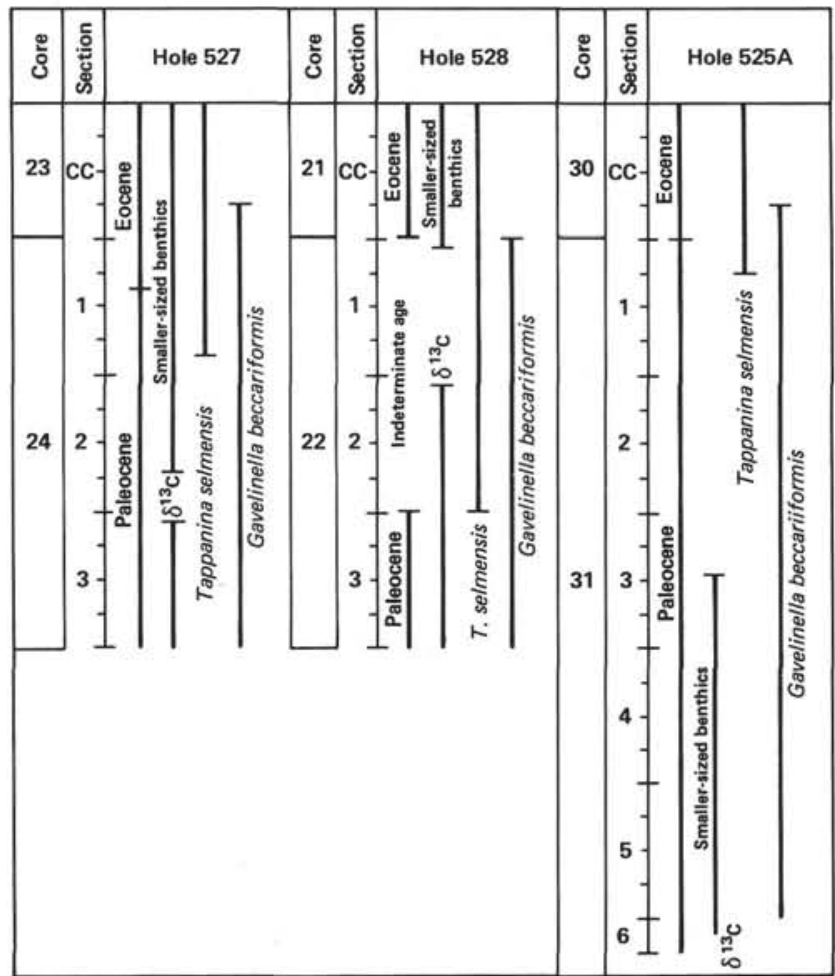

Figure 6. Stratigraphy of events across the Paleocene/Eocene boundary in Holes 527, 528, and 525A. The Paleocene/Eocene boundary indicated on the figure is estimated on the basis of planktonic foraminifers according to the zonation of Hardenbol and Berggren (1978). Also plotted are the levels of the extinction of Gavelinella beccariformis and origination of Tappanina selmensis, the level of the carbon isotope excursion (Shackleton and Hall, in press), and the point above which benthic foraminifers become smaller in size.
Table 1. Commonly occurring Miocene-Pliocene benthic foraminifers in Hole 525B.

\begin{tabular}{|c|c|c|}
\hline $\begin{array}{c}\text { Core- } \\
\text { Section } \\
(\text { level in } \mathrm{cm})\end{array}$ & Zone & Species and genera \\
\hline \multicolumn{3}{|c|}{ Through the upper Miocene } \\
\hline $16-2,100$ & N17 & $\begin{array}{l}\text { Osangularia culter, Uvigerina hispido-costata, Pyrgo } \\
\text { spp., Globocassidulina subglobosa, Chrysalogo- } \\
\text { nium spp. }\end{array}$ \\
\hline $18-1,53$ & N16 & $\begin{array}{l}\text { Eggerella bradyi, Planulina rugosa, G. subglobosa, } \\
\text { Oridorsalis umbonatus, Pyrgo spp. }\end{array}$ \\
\hline $19-2,66$ & N16 & $\begin{array}{l}\text { O. culter, Oridorsalis umbonatus, Textularia mexi- } \\
\text { cana, Gyroidinoides altiformis, Laticarinina } \\
\text { halophora, Globocassidulina subglobosa, Cibici- } \\
\text { doides gramulosus. }\end{array}$ \\
\hline $24-2,64$ & N16 & $\begin{array}{l}\text { O. umbonatus, Gyroidinoides altiformis, Angulo- } \\
\text { gerina angulosa, Triloculina spp., C. granulosus, } \\
\text { Nuttallides umbonifera, Stilostomella lepidula. }\end{array}$ \\
\hline $25-2,55$ & N16 & $\begin{array}{l}\text { Globocassidulina subglobosa, Osangularia culter, C. } \\
\text { granulosus, Planulina rugosa, N. umbonifera, } \\
\text { Epistominella exiguua, Karreriella sp. }\end{array}$ \\
\hline $26-2,120$ & N16 & $\begin{array}{l}\text { U. hispido-costata, Bulimina alazanensis, } G \text {. subglo- } \\
\text { bosa, B. striata mexicana, S. lepidula. }\end{array}$ \\
\hline $27-2,60$ & N15 & $\begin{array}{l}\text { Planulina renzi, Cibicides wuellerstor } f i \text {, O. culter, } \\
\text { G. subglobosa, C. granulosus, Chrysalogonium } \\
\text { sp. }\end{array}$ \\
\hline $29-2,73$ & N15 & $\begin{array}{l}\text { Oridorsalis umbonatus, G. subglobosa, S. lepidula, } \\
\text { N. umbonifera, Pullenia quinqueloba, Uvigerina } \\
\text { auberiana, B. alazanensis, L. halophora. }\end{array}$ \\
\hline $31-2,50$ & N14 & $\begin{array}{l}\text { Heterolepa kullenbergi, G. subglobosa, Chrysalogo- } \\
\text { nium sp., Vulvulina spinosa, Ehrenbergina } \\
\text { spinossissima, L. bullbrooki, Osangularia culter, } \\
\text { Gavelinella semicribrata, N. umbonifera, B. } \\
\text { alazanensis. }\end{array}$ \\
\hline $32-3,55$ & N14 & $\begin{array}{l}\text { S. lepidula, B. alazanensis, Globocassidulina sub- } \\
\text { globasa, O. culter, Planulina renzi, C. wueller- } \\
\text { storfi, Bolivina subaenariensis, Oridorsalis } \\
\text { umbonatus. }\end{array}$ \\
\hline $34-2,55$ & N14 & $\begin{array}{l}\text { Bulimina alazanensis, } B \text {. striata mexicana, } G \text {. } \\
\text { subglobosa, } O \text {. umbonatus, } N \text {. umbonifera, } B \text {. } \\
\text { subaenariensis. }\end{array}$ \\
\hline $35-2,55$ & N14 & $\begin{array}{l}\text { C. wuellerstorfi, N. umbonifera, P. renzi, U. pyg- } \\
\text { maea, E. bradyi, Siphonodosaria modesta, O. } \\
\text { umbonatus, Cibicidoides cf. spirolimbatus, } \\
\text { Pullenia bulloides, Cassidulina crassa. }\end{array}$ \\
\hline $36-2,55$ & N14 & $\begin{array}{l}\text { G. subglobosa, E. bradyi, U. hispido-costata, } N \text {. } \\
\text { umbonifera, Karreriella bradyi, C. wuellerstorfi, } \\
\text { Cibicidoides cf. spirolimbatus, O. umbonatus, } \\
\text { B. alazanensis. }\end{array}$ \\
\hline \multicolumn{3}{|c|}{ Through the Pliocene } \\
\hline $1, \mathrm{CC}$ & $\mathrm{N} 23$ & $\begin{array}{l}\text { G. subglobosa, Sigmoilopsis schlumbergeri, } O . \\
\text { umbonatus, } H . \text { kullenbergi, } C \text {. wuellerstorfi, B. } \\
\text { alazanensis, L. halophora, N. umbonifera, E. } \\
\text { bradyi, U. hispido-costata, U. peregrina. }\end{array}$ \\
\hline $2, \mathrm{CC}$ & $\mathrm{N} 22$ & $\begin{array}{l}\text { Pyrgo spp., G. subglobosa, } H . \text { rugasa, } H \text {. kullen- } \\
\quad \text { bergi, } U \text {. hispido-costata, O. umbonatus, No- } \\
\quad \text { torotalia sp., Pullenia bulloides, Triloculina spp. }\end{array}$ \\
\hline $3, \mathrm{CC}$ & $\mathrm{N} 22$ & $\begin{array}{l}U . \text { peregrina, U. pygmaea, L. halophora, } C \text {. wuel- } \\
\text { lerstorfi, H. kullenbergi, B. alazanensis, } S \text {. } \\
\text { schlumbergeri. }\end{array}$ \\
\hline $4, \mathrm{CC}$ & P15-6 & $\begin{array}{l}\text { U. pygmaea, Planulina spp., G. subglobosa, Nuttal- } \\
\text { lides umbonifera, Pyrgo spp., S. schlumbergeri. }\end{array}$ \\
\hline $5, \mathrm{CC}$ & P14 & $\begin{array}{l}\text { O. umbonatus, Stilostomella lepidula, L. ha- } \\
\text { lophora, } H \text {. kullenbergi, Pleurostomella al- } \\
\text { ternans, Osangularia culter, Pullenia bulloides, } \\
\text { C. wuellerstorfi, U. hispido-costata, S. schlum- } \\
\text { bergeri, } N \text {. umbonifera, Gavelinella semicribra- } \\
\text { ta. }\end{array}$ \\
\hline $6, \mathrm{CC}$ & P13 & $\begin{array}{l}\text { C. wuellerstorfi, Bulimina consanguinea, N. umbo- } \\
\text { nifera, } O \text {. culter, Textularia mexicana, U. pyg- } \\
\text { maea, Globocassidulina subglobosa, B. alaza- } \\
\text { nensis, Gavelinella semicribrata, Oridorsalis } \\
\text { umbonatus. }\end{array}$ \\
\hline $7, \mathrm{CC}$ & P13 & $\begin{array}{l}\text { Stilostomella lepidula, } C . \text { wuellerstorfi, miliolid } \\
\text { fragments, U. auberiana, U. pygmaea, T. mexi- } \\
\text { cana, } H \text {. kullenbergi, O. umbonatus, Osangula- } \\
\text { ria culter, Pullenia quinqueloba, U. hispido- } \\
\text { costata, L. halophora. }\end{array}$ \\
\hline $9, \mathrm{CC}$ & P12 & $\begin{array}{l}\text { N. umbonifera, Globocassidulina subglobosa, } P \text {. } \\
\text { bulloides, O. umbonatus, U. hispido-costata, E. } \\
\text { bradyi, S. lepidula, C. wuellerstorfi, H. kullen- } \\
\text { bergi. }\end{array}$ \\
\hline $11, \mathrm{CC}$ & P1 1 & $\begin{array}{l}\text { Miliolid fragments, } U \text {. hispido-costata, } E \text {. bradyi, } \\
G \text {. subglobosa, } P \text {. bulloides, } C \text {. wuellerstorfi, } \\
\text { various lagenids. }\end{array}$ \\
\hline $12, \mathrm{CC}$ & PI 1 & $\begin{array}{l}\text { G. subglobosa, miliolid fragments, } H \text {. kullenbergi, } \\
\text { Oridorsalis umbonatus, Triloculina spp., Pyrgo } \\
\text { spp. }\end{array}$ \\
\hline $15, \mathrm{CC}$ & PI 1a & $\begin{array}{l}\text { Uvigerina hispida, } H \text {. rugosa, G. subglobosa, Pyrgo } \\
\text { spp., S. schlumbergeri, O. umbonatus. }\end{array}$ \\
\hline
\end{tabular}

Note: Foraminifers were picked from the $>149 \mu \mathrm{m}$ fractions. Samples are zoned according to Berggren (1972). 


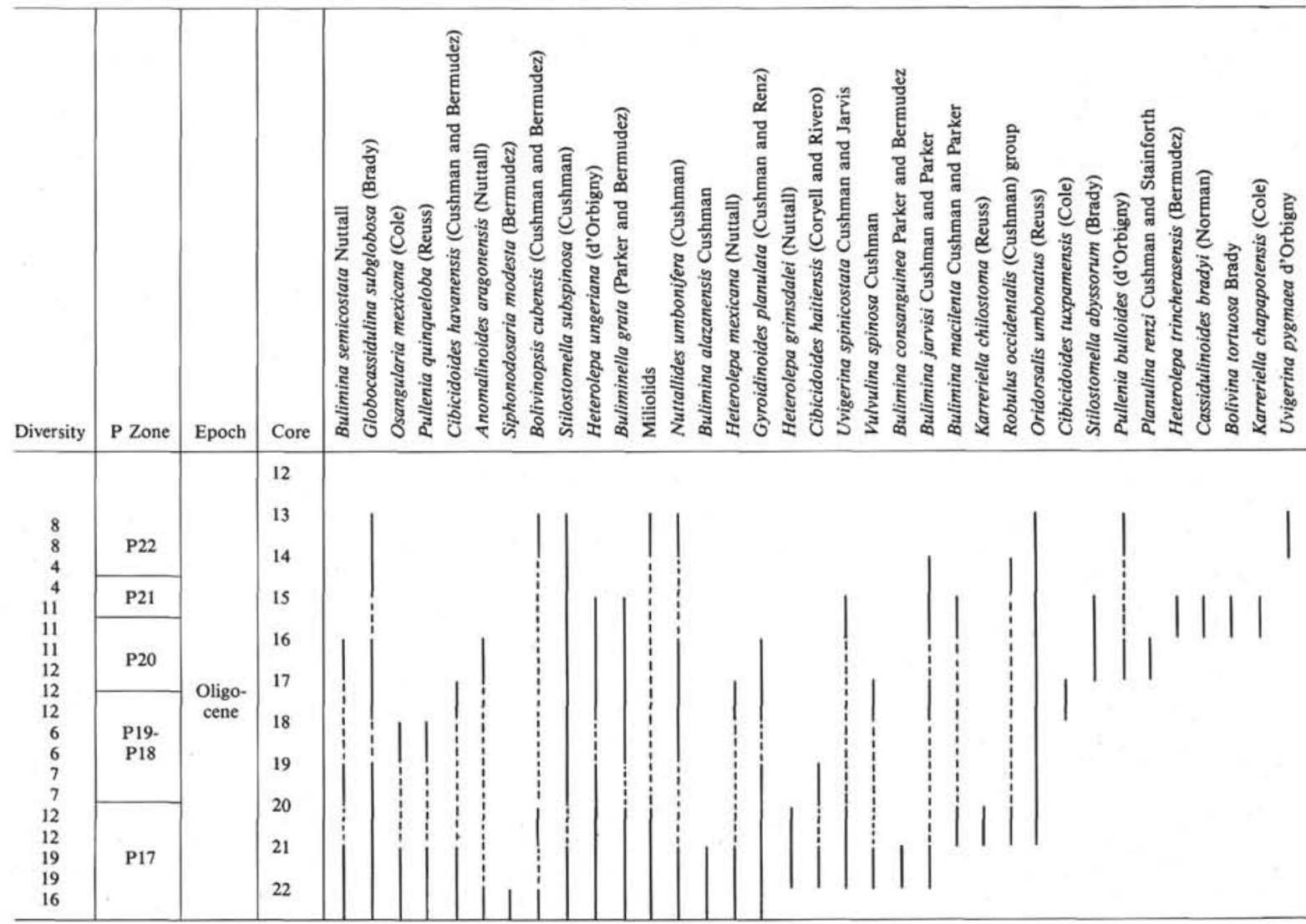

Figure 7. Stratigraphic ranges of most common benthic foraminifers through the Oligocene at Site 529. Samples are zoned according to the zonation of Hardenbol and Berggren (1978).

Table 2. Most common Maestrichtian-Paleogene benthic foraminifers at the shallower Site 525, intermediate Site 528, and deep Site 527 on the Walvis Ridge.

\begin{tabular}{|c|c|c|c|c|c|}
\hline Site & Maestrichtian & Lower Paleocene & Upper Paleocene & Lower Eocene & $\begin{array}{l}\text { Mid-upper } \\
\text { Eocene }\end{array}$ \\
\hline 527 & $\begin{array}{l}\text { Gyroidinoides } \\
\text { Lenticulina } \\
\text { Gavelinella }\end{array}$ & $\begin{array}{l}\text { Nuttallides } \\
\text { Stilostomella } \\
\text { G. beccariformis }\end{array}$ & $\begin{array}{l}\text { Aragonia } \\
\text { N. truempyi } \\
\text { S. abyssorum } \\
\text { G. beccariformis }\end{array}$ & $\begin{array}{l}\text { N. truempyi } \\
\text { G. subglobasa } \\
\text { S. gracillima } \\
\text { A. velascoensis }\end{array}$ & $\begin{array}{l}\text { Anomalina } \\
\text { N. truempyi } \\
\text { A. aragonensis } \\
\text { S. gracillima }\end{array}$ \\
\hline 528 & $\begin{array}{l}\text { Gyroidinoides } \\
\text { Cibicidoides }\end{array}$ & $\begin{array}{l}\text { Gavelinella beccariformis } \\
\text { Nuttalides truempyi } \\
\text { Lenticulina }\end{array}$ & $\begin{array}{l}\text { Pleurostomella } \\
\text { N. truempyi } \\
\text { Nodosarids }\end{array}$ & $\begin{array}{l}\text { Pleurostomella } \\
\text { N. truempyi } \\
\text { Nodosaridds }\end{array}$ & $\begin{array}{l}\text { A. aragonensis } \\
\text { N. truempyi } \\
\text { Anomalina }\end{array}$ \\
\hline 525 & $\begin{array}{l}\text { Gavelinella } \\
\text { Praebulimina } \\
\text { Gyroidinoides } \\
\text { Lenticulina. }\end{array}$ & $\begin{array}{l}\text { N. truempyi } \\
\text { G. beccariformis } \\
\text { Anomalina } \\
\text { Cibicidoides }\end{array}$ & $\begin{array}{l}\text { G. beccariformis } \\
\text { N. truempyi } \\
\text { Vulvulina }\end{array}$ & $\begin{array}{l}\text { N. truempyi } \\
\text { Osangularia } \\
\text { Stilostomella } \\
\text { Vulvulina }\end{array}$ & $\begin{array}{l}\text { N. truempyi } \\
\text { O. mexicana } \\
\text { S. abyssorum } \\
\text { Nodosariids }\end{array}$ \\
\hline
\end{tabular}

Note: Genera and/or species are listed in order of abundance.

At Site 529 over 35 species were identified through the nearly complete Oligocene section (Fig. 7). Diversities and the Benthic Number are relatively low (Fig. 10); diversity decreases slightly above Zone P17, increases again from Zone P19-P20, then drops in Zones P21P22.

Lower Oligocene faunas (Fig. 10) at Site 529 are dominated by stilostomellids and Oridorsalis umbonatus with lesser percentages of cibicidids and the agglutinants. By the upper Oligocene the percentages of stilostomellids increases, with nearly equal but subsidiary amounts of Oridorsalis, cibicidids, and buliminids. Agglutinants drop markedly in importance by the Oligocene.
For comparative purposes the generic contents of faunas from two intermediate-depth sites, 525 and 363, farther to the east on the Walvis Ridge, are shown in Figure 11. Faunas at these two sites are markedly different from those at either Site 526 or Site 529 .

Comparison of species between Sites 526 and 529 indicates that many species are unique to one or the other site. Species found only at Site $\mathbf{5 2 6}$ are Uvigerina semivestita, U. spinulosa, Rectuvigerina postprandia, Bolivina tectiformis, Discocibicides sp., U. camagueyana, Oridorsalis ecuadorensis, Gavelinella semicribrata, Robulus peregrinus, Cibicides lobatulus, Sphaeroidina bulloides, Cassidulina crassa, Cibicidoides whitei, C. io, and Nodogenerina sp.

Species found at Site 529, but not at Site 526, include Bulimina consanguinea, $B$. semicostata, Uvigerina spinicostata, Buliminella grata, Cassidulinoides bradyi, Nuttalides umbonifera, Bulimina jarvisi, Cibicidoides haitiensis, and Bolivinopsis delicatulus.

Abundances of several species among the Oligocene sites appear to vary with depth, as shown in Figure 12. Although Buliminella grata, O. umbonatus, and Globocassidulina subglobosa occur at all four sites, they are significantly more abundant at the deeper Site 529 and least abundant at the shallowest Site 526. The opposite pattern is demonstrated by Bulimina alazanensis, which is more abundant at Site 526 than at the the other three sites. Uvigerina spinicostata is not present at Site $\mathbf{5 2 6}$ 


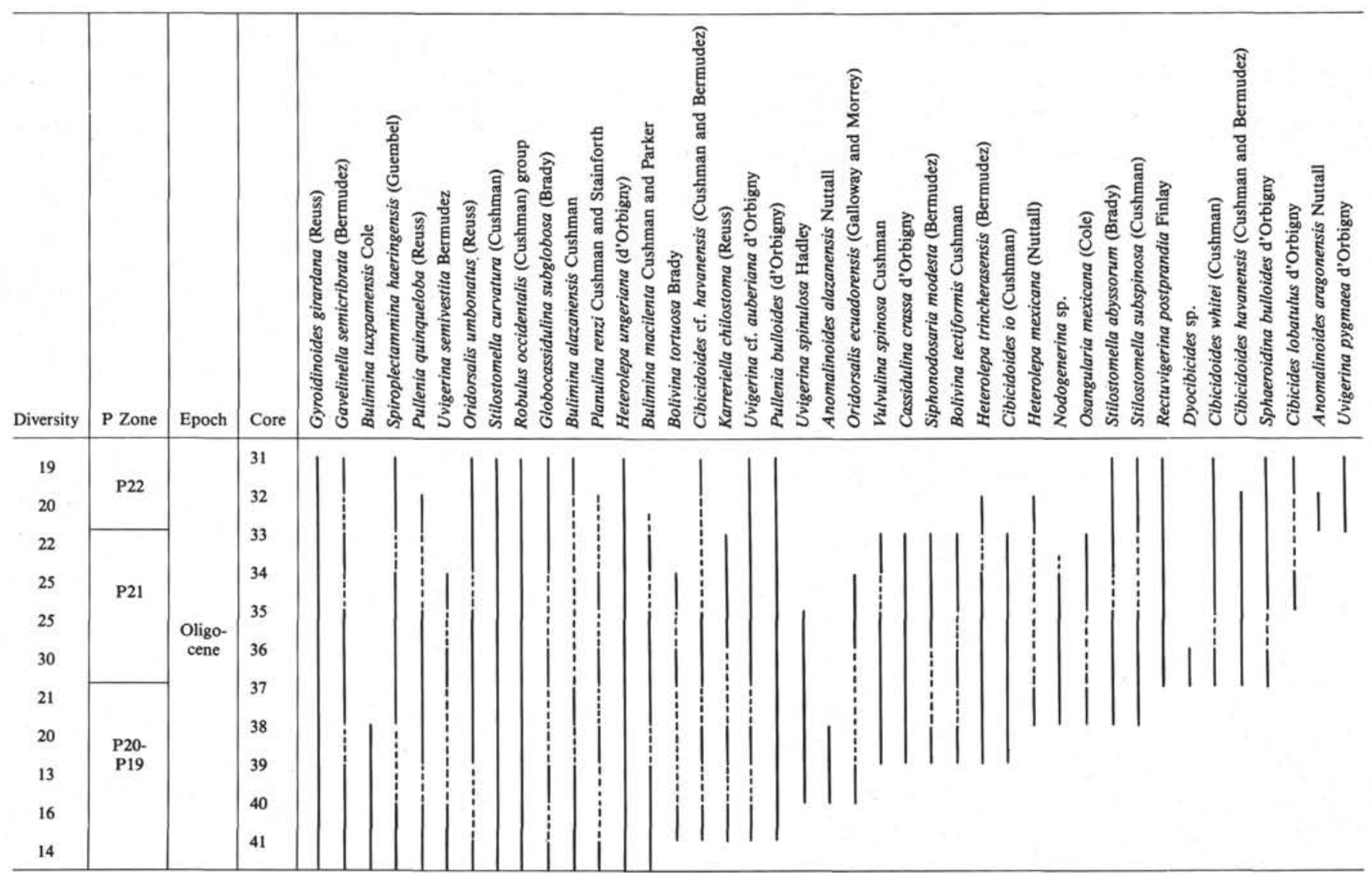

Figure 8. Stratigraphic ranges of most common benthic foraminifers through the Oligocene at Site 526. Samples are zoned according to the zonation of Hardenbol and Berggren (1978).

but grades from more to less abundant through depth. Bulimina consanguinea, a form of B. alazanensis with confluent costae, is present at the deepest Site 529 and is most common at the two intermediate depth sites, but is absent at the shallowest Site 526 .

Comparison of the Benthic Numbers of the four Walvis sites also demonstrates a gradation: larger numbers of benthics are characteristic of the shallowest site; the smallest numbers are characteristic of the deepest site (Fig. 10).

\section{Pliocene}

Similar but less detailed analyses were made of Sites 525 and Site 527 through the Pliocene (Figs. 13-14). Benthic foraminifers in $0.5 \mathrm{~g}$ of sediment from two fractions ( $>355 \mu \mathrm{m}$ and $<355 \mu \mathrm{m},>149 \mu \mathrm{m})$ were picked and counted from Hole 525B. These can be compared with counts from the $<355 \mu \mathrm{m},>149 \mu \mathrm{m}$ fractions from Site 527 (Fig. 13).

As in the Oligocene the Benthic Number is greater at the shallower site during the Pliocene. The one sample in Zone N17 where that number is higher at the deeper Site 527 reflects the extreme dissolution of planktonic foraminifers in that interval. Above Section 527-14-2, the Benthic Number at Site 527 is less than 100 until the uppermost Pliocene, when it increases both here and at Site 525 . The greatest difference between the two sites occurs during the mid Pliocene, when values at Site 525 reach over 600 specimens $/ 0.5 \mathrm{~g}$ sediment.

The major change in benthic faunas at Site 525 occurs in the interval from Zones Pl4 through Pl6, when several species including Nuttallides umbonifera and $\mathrm{Ci}$ bicides wuellerstorfi increase markedly in abundance. There is little discernible change in the faunas accompanying the large increase in numbers of benthics in Zone Pl3.

Comparison of abundances of $C$. wuellerstorfi in the fractions $>355 \mu \mathrm{m}$ and $<355 \mu \mathrm{m},>149 \mu \mathrm{m}$ is representative of other species as well. That is, there is little similarity between the abundance of this species in the two fractions, and little parallelism in the curves of their abundance through the Pliocene. Since there is a much larger population in the $<355 \mu \mathrm{m},>149 \mu \mathrm{m}$ fraction, the abundance figures for species in this fraction are probably more accurate.

At Site 527 the Benthic Number is highest in the uppermost Miocene, when the site first rises above the CCD, and again in the uppermost Pliocene, where fragment counts indicate a decrease in dissolution of carbonates (Fig. 13). The Benthic Number reaches its minimum in the mid Pliocene in Zone P13. There is significant specific variation through the Pliocene. Uvigerina spp. and $C$. wuellerstorfi reach peak abundances in Zone PI1. $C$. wuellerstorfi and Globocassidulina subglobosa then reach 


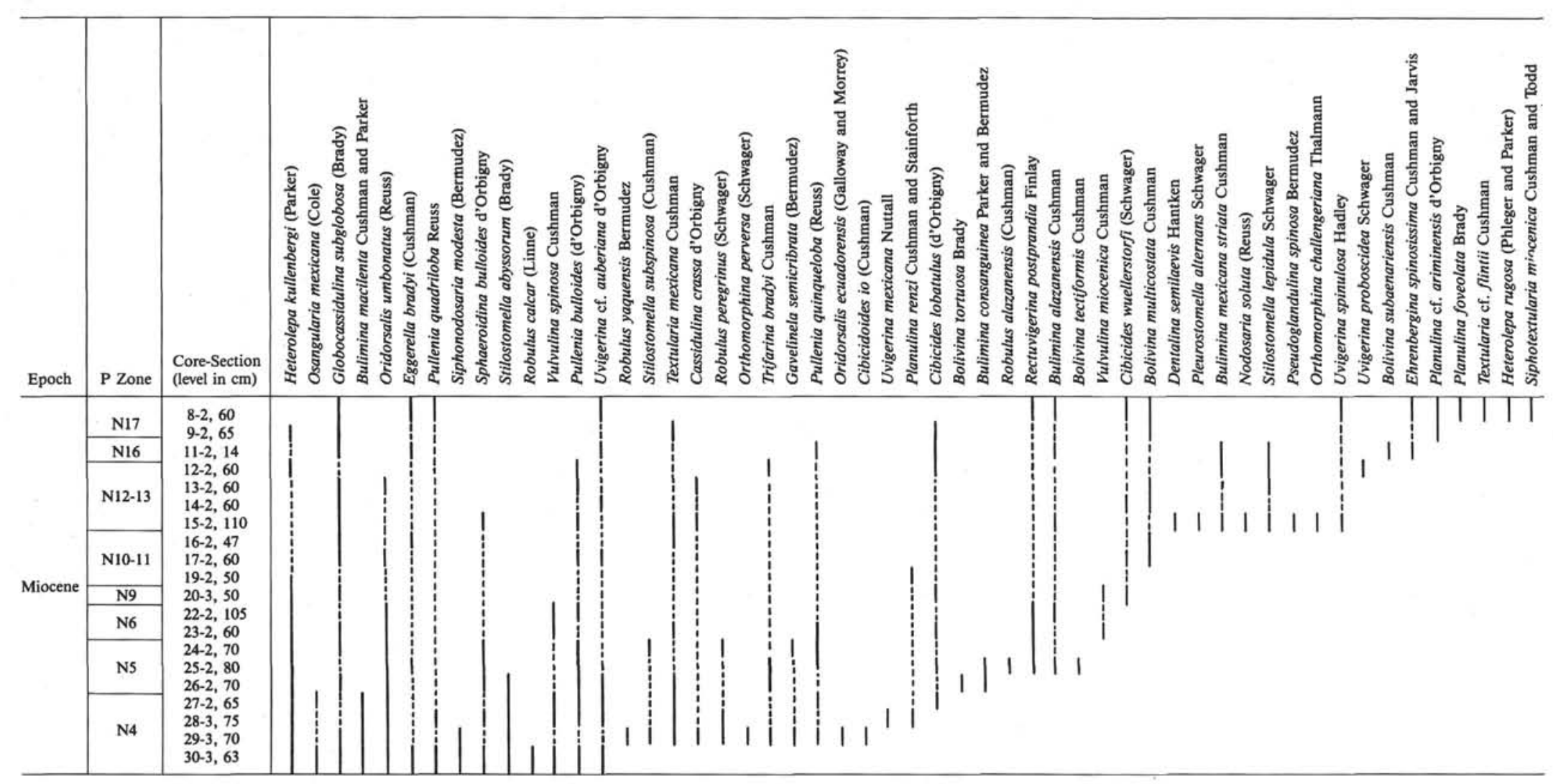

Figure 9. Stratigraphic ranges of most common benthic foraminifers through the Miocene of Hole 526A. Samples are zoned according to the zonation of Berggren (1972). 

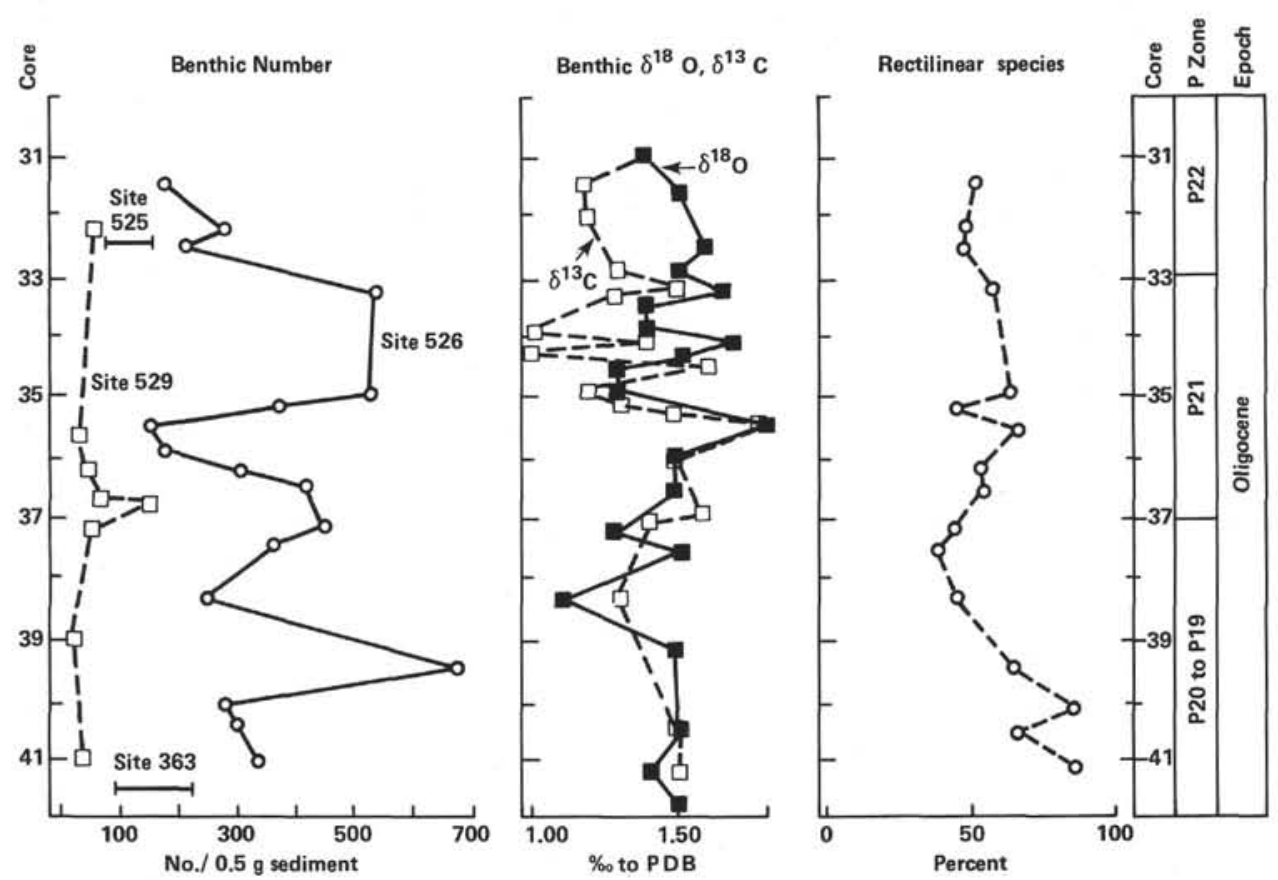

Figure 10. Counts of benthic foraminiferal faunas plotted against the oxygen and carbon isotope curves for the Oligocene (Shackleton et al., in press). Benthic numbers for four sites are plotted against time through the Oligocene according to the zonation and timescale of Hardenbol and Berggren (1978). The percentage of rectilinear species includes all specimens of Nodosaria, Bulimina, Uvigerina, Stilostomella, Pleurostomella, Dentalina, Siphonodosaria, Rectuvigerina, and Bolivina.
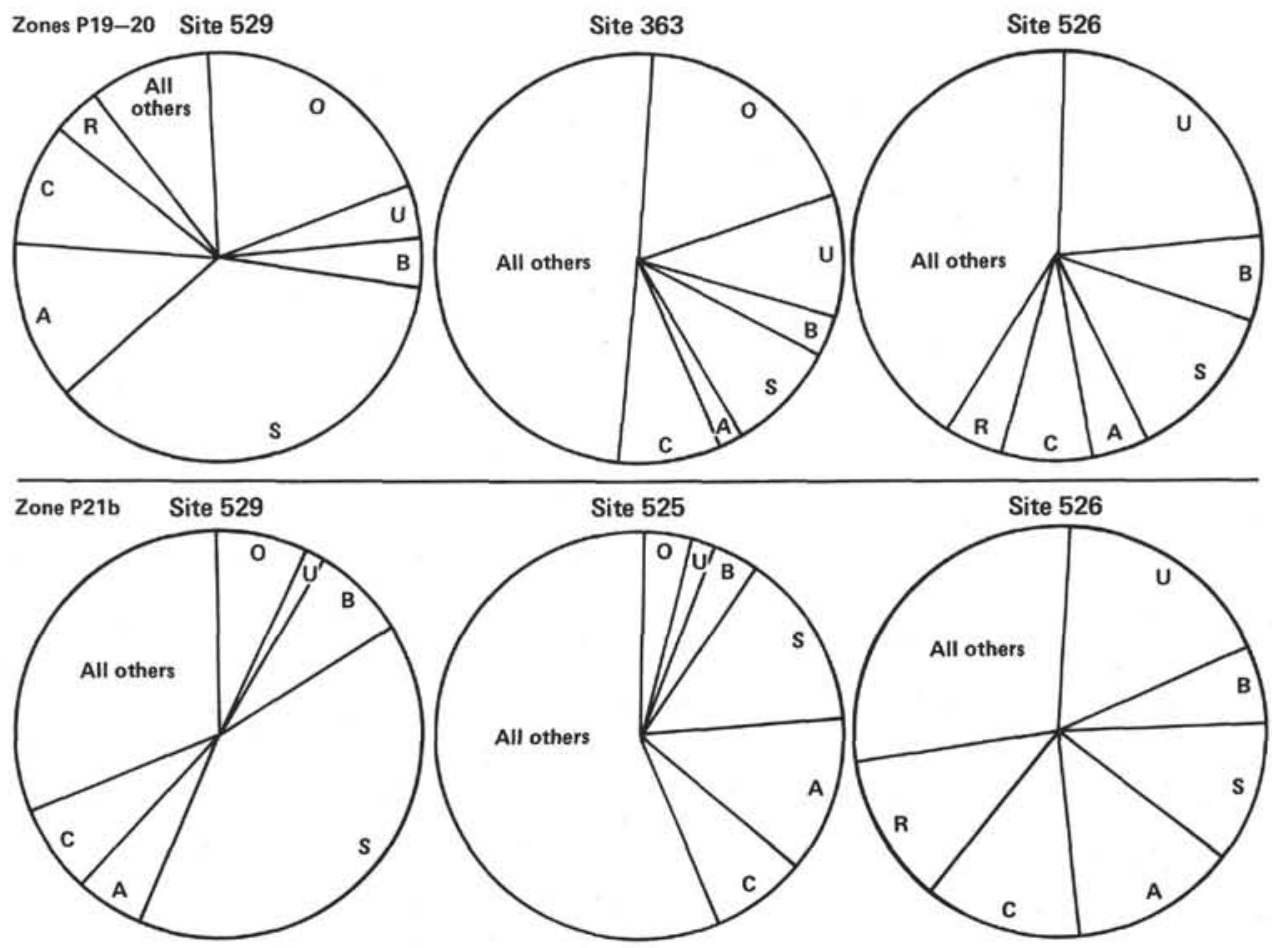

Figure 11. Percentages of the most common genera found at Sites 525, 526, 363, and 529 in Oligocene Zones P20 and P21b. Generic percentages are expressed as degrees of arc and plotted using the following symbols: U, Uvigerina; B, Bulimina, A, agglutinants, C, Cibicidoides, R, Robulus, S, Stilostomel$\mathrm{Ia}$, and $\mathrm{O}$, Oridorsalis. Samples were zoned according to the zonation of Hardenbol and Berggren (1978). 


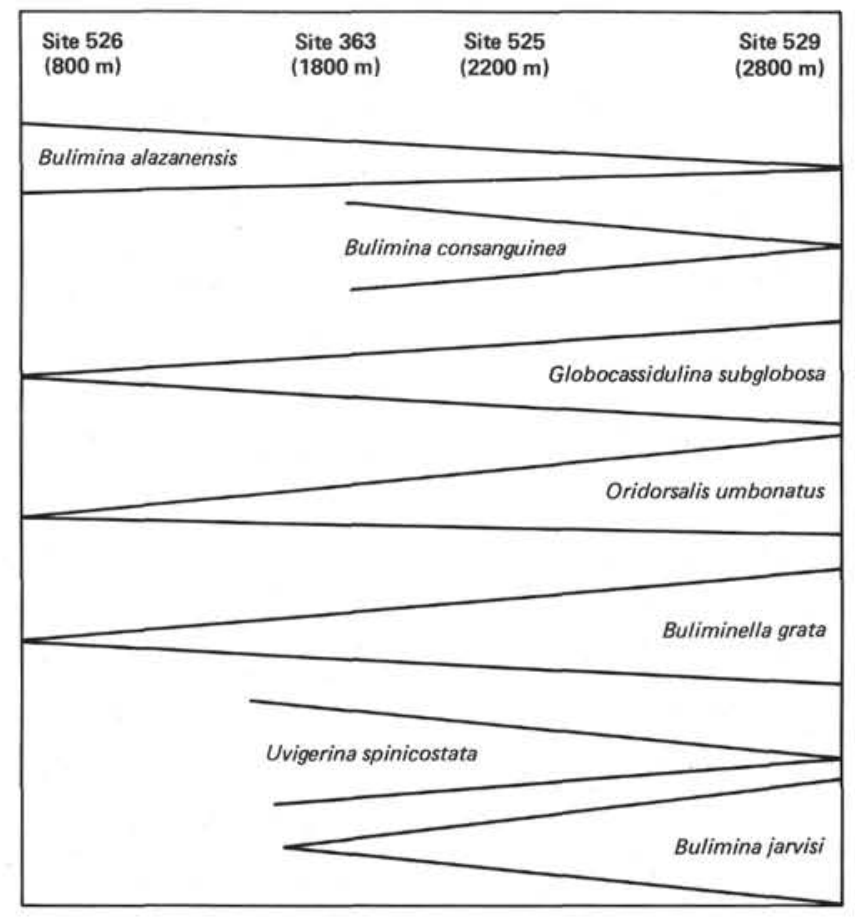

Figure 12. Gradational abundances of various benthic species through depth at Sites 525, 526, 363, and 529 during the Oligocene. Abundance on this diagram is represented by the direction and amount of opening of the elongate $\mathrm{V}$ bracketing each specific name. That is, Bulimina alazanensis grades from less abundant at the deepest Site 529 to most abundant at the shallowest Site 526. Paleodepths were taken from the age-depth curve shown in Figure 5.

an abundance peak in Zone P13. The porcellaneous foraminifers demonstrate a large increase in their numbers near the top of the Pliocene in Zones Pl5 to Pl6.

Comparison of the faunas between the two sites demonstrates that:

1) Nuttallides umbonifera is more common at the deeper Site 527 through most of the Pliocene, until Zones $\mathrm{Pl} 5$ to Pl6, where it increases markedly at the shallower Site 525, but decreases at Site 527.

2) Uvigerina spp. are more common at the shallower Site 525 except near the top of Zone Pl1, where a $U v i$ gerina maximum is reached at Site 527. This maximum is diachronous with the uvigerinid maximum at Site $\mathbf{5 2 5}$.

3) Porcellaneous foraminifers are more abundant and common at the deeper Site 527.

4) There appears to be greater amplitude of specific variability at the deeper Site 527 .

\section{Benthic Foraminifers as Paleodepth Estimators}

The presence at Site 526 of large and distinct populations of species of the genus Uvigerina through the Oligocene provided a unique opportunity to test the utility of these forms to predict paleodepths, in comparison with the backtrack estimates of the paleodepths of the site during the Oligocene. Paleodepths for the Site 526 sediments were estimated from the upper Eocene through the Oligocene (Cores 45-30) on the basis of uvigerinid depth indices determined by Boersma (1974) as shown in Table 3. Plots of these depth estimates (Fig. 15) com-
Table 3. Species of the genus Uvigerina present through the upper Eocene and Oligocene of Hole 526A.

\begin{tabular}{|c|c|c|c|}
\hline Core & Zone & $\begin{array}{l}\text { Estimated } \\
\text { paleodepth } \\
\text { (m) }\end{array}$ & Species present \\
\hline $43-41$ & P15 & $200-500$ & $\begin{array}{l}\text { Uvigerina semivestita, } U . \text { camaguey- } \\
\text { ana, } U \text {. cocoaensis }\end{array}$ \\
\hline 42 & P16-17 & $300-600$ & $U$. semivestita, $U$. mexicana \\
\hline $41-40$ & P19-20 & $200-500$ & $U$. semivestita, $U$. camagueyana \\
\hline 39 & P20 & $600-800$ & $U$ semivestita trans. spinulosa \\
\hline 38 & P20 & $600-1000$ & U. spinulosa \\
\hline 37-33 & P21 & $600-1000$ & $\begin{array}{l}\text { U. spinulosa with striae restricted to } \\
\text { individual chambers }\end{array}$ \\
\hline 33-30 & P22 & $? 600-1000$ & $\begin{array}{l}\text { Rectuvigerina postprandia and } U . \\
\text { auberiana, not depth-diagnostic }\end{array}$ \\
\hline
\end{tabular}

Note: Samples are zoned according to the zonation of Hardenbol and Berggren (1978). Estimated paleodepths are assigned according to the criteria of Boersma (1974).

pared with the backtrack estimate derived from Figure 5 demonstrate the close correlation of the two estimators. In the upper Eocene and lower Oligocene the uvigerinids give slightly shallower depth estimates than the backtrack curve, but by the upper Oligocene the two curves overlap.

Since Eocene sediments of Zone P14 contain calcareous algae and other carbonate bank material but no planktonic foraminifers, it is possible that the backtrack estimates are too deep. Otherwise agreement between the two curves is excellent and corroborates the potential of uvigerinids to estimate paleodepths, at least through the depth range from $\sim 200-800 \mathrm{~m}$ in the Eocene to upper Oligocene.

\section{Benthic Faunas and Burrowing}

Properties other than those of bottom watermasses may be determining the content of benthic foraminiferal faunas. Postdepositional processes within the sediment, for example, may significantly alter the benthic thanatocoenoses. Since cores from the Miocene of Hole 525A contain distinct bioturbation cycles, benthic foraminifers and other microfossils through these cycles were picked every $10 \mathrm{~cm}$ from $0.5 \mathrm{~g}$ of sediment of the fraction $<355 \mu \mathrm{m},>149 \mu \mathrm{m}$. The foraminifers were counted and are compared with sedimentary evidence of burrowing in Figure 16. Carbonate dissolution is estimated by counting the numbers of fragments in 350 particles from the same fraction.

Two types of burrowing cycles are indicated in Figure 16 ; the first, from $75-90 \mathrm{~cm}$, is associated with an intense dissolution episode at $80 \mathrm{~cm}$; and the second, at $35-47 \mathrm{~cm}$ and $95-100 \mathrm{~cm}$, is not associated with evidence of intensified dissolution.

Characteristic of the burrowing and dissolution cycle at $80 \mathrm{~cm}$ are

1) a major increase in fragmentation;

2) a minimum Benthic Number (the number of benthic individuals in $0.5 \mathrm{~g}$ of sediment);

3) a decrease in the number of echinoid remains;

4) a maximum of agglutinants and a maximum abundance of the agglutinated species, Vulvulina spinosa;

5) a decrease in the numbers of stilostomellids; and 
Age Zone $\begin{gathered}\text { Core- } \\ \text { Section }\end{gathered}$

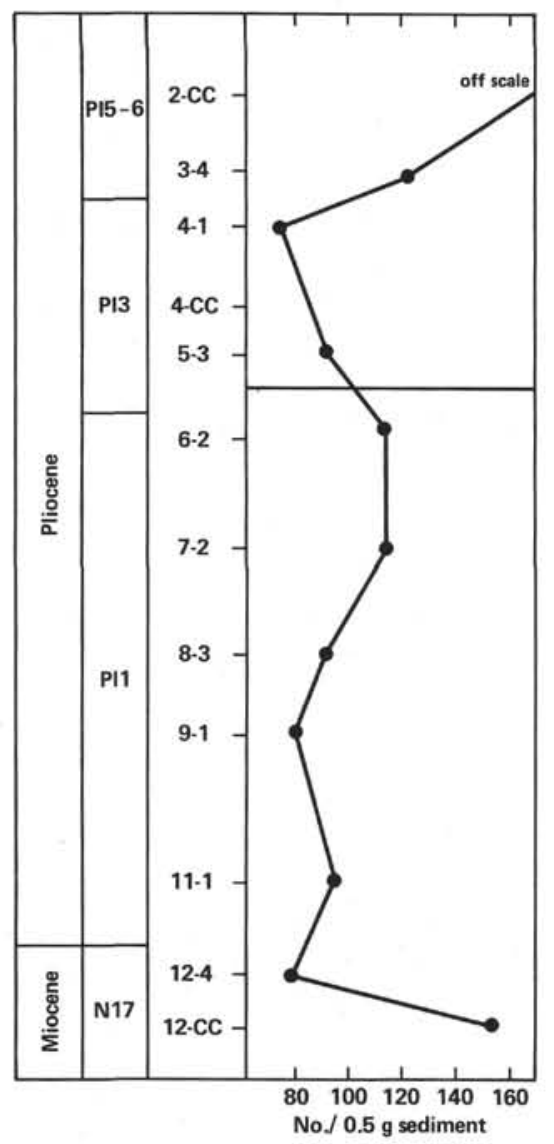

Cibicides wuellerstorfi $(\bullet)$

Globocassidulina subglobosa (X)

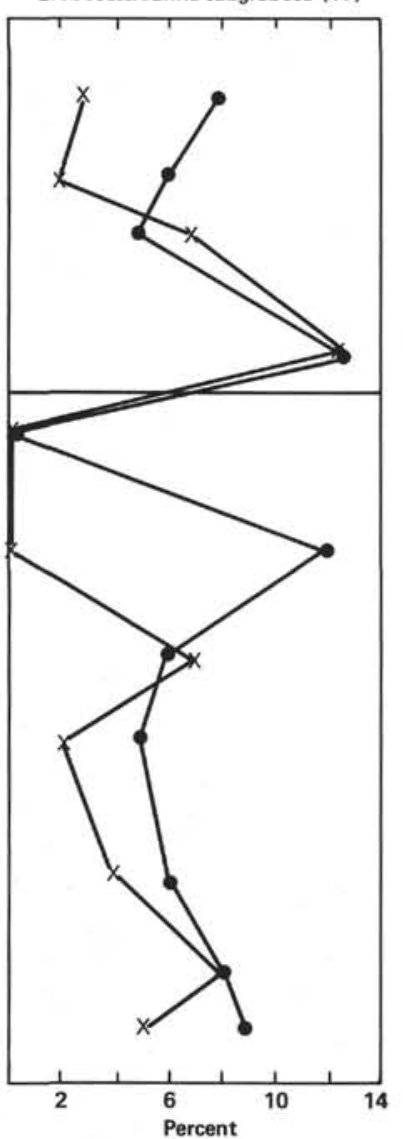

Porcellaneous spp.

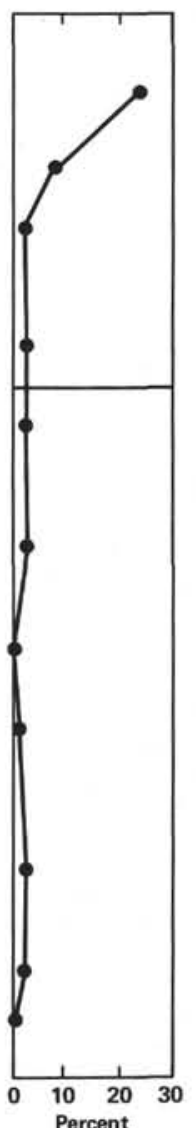

No. fragments (•)

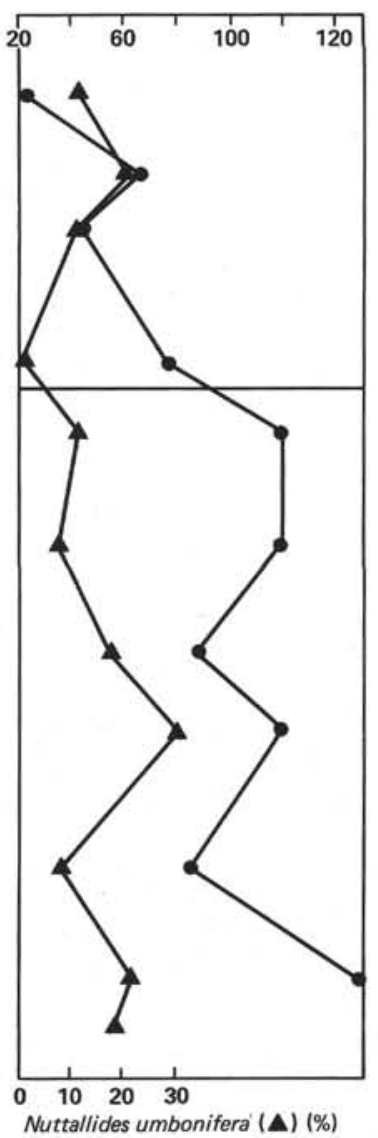

Uvigerina

spp.

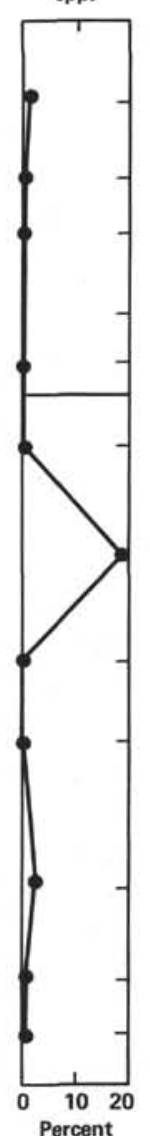

Figure 13. Percentages of benthic foraminiferal species, fragments, porcellaneous genera, and the Benthic Number through the Pliocene at Site 527. Foraminifera were picked and counted from $0.5 \mathrm{gm}$ of sediment of the $<355>149 \mu \mathrm{m}$ fraction. Samples were zoned according to the zonation of Berggren (1973).
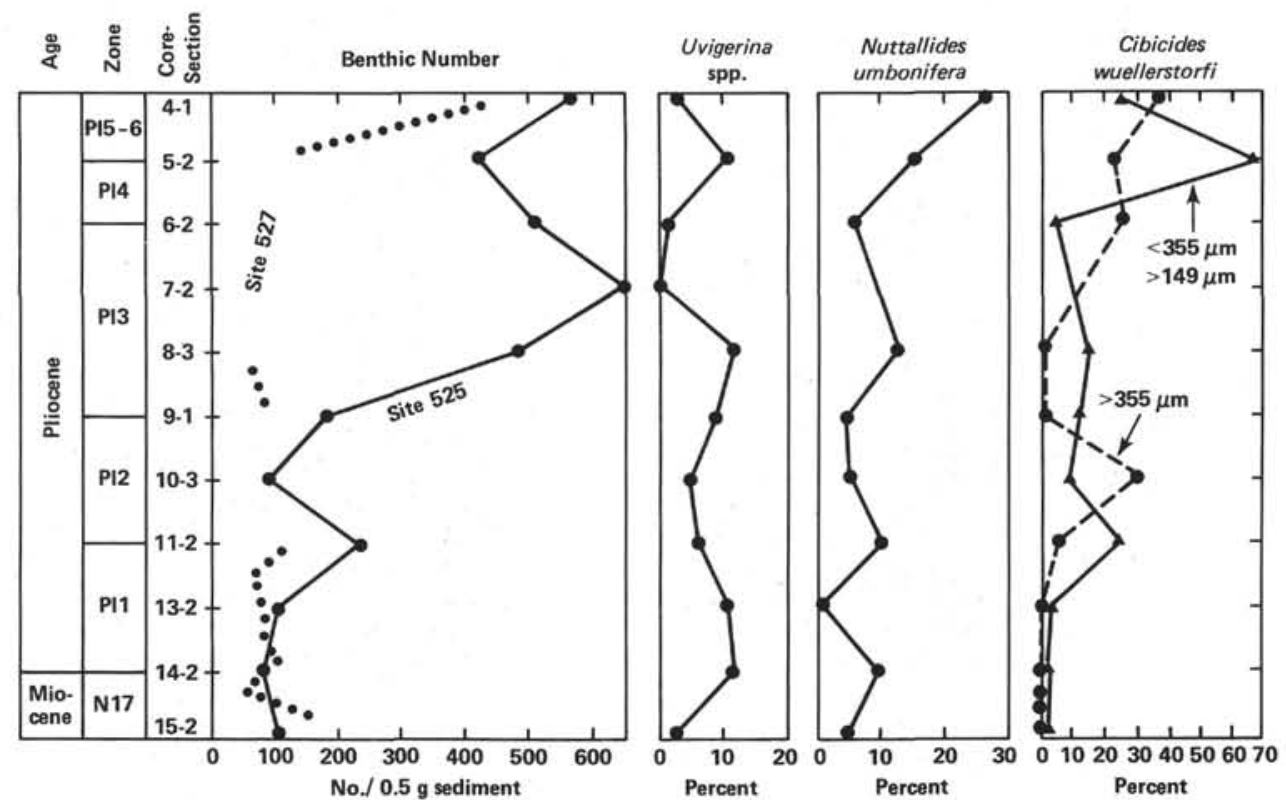

Figure 14. Percentages of benthic foraminiferal species and genera in Section 525A-12-3 and the Benthic Number through the Pliocene of Holes 525B and Hole 527. Abundances of Cibicides wuellerstorfi in the $>355 \mu \mathrm{m}$ and the $<355 \mu \mathrm{m},>149 \mu \mathrm{m}$ fractions are plotted for comparison. Samples were zoned according to the zonation of Berggren (1973). 


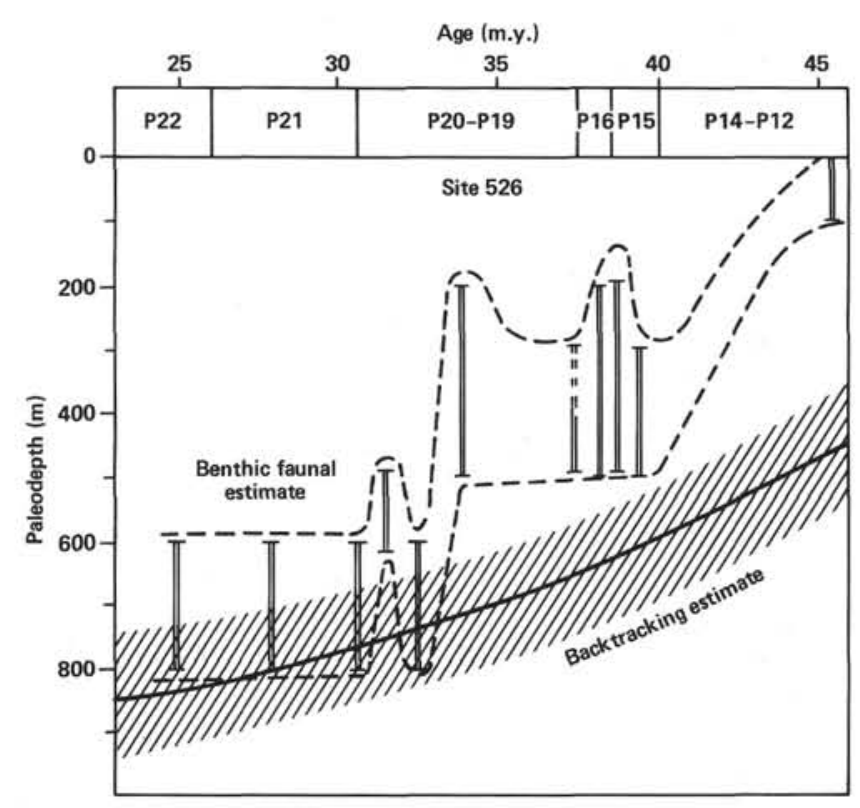

Figure 15. Comparison of paleodepth estimates of Site 526 during the Eocene-Oligocene based on benthic faunas and the age-depth curve in Figure 5. Faunal estimators, species of the genus Uvigerina, are listed in Table 3. Samples were assigned ages according to the timescale and zonation of Hardenbol and Berggren (1978).
6) a small increase in the numbers of gyroidinids and cibicidids.

Typical of the second type of burrowing level around $40 \mathrm{~cm}$ are

1) a large drop in the Benthic Number;

2) a slight decrease in the abundance of echinoid remains;

3) a slight decrease in the numbers of stilostomellids and gyroidinids;

4) no appreciable change in the agglutinants; and

5) slight increases in the numbers of Heterolepa kullenbergi and Globocassidulina subglobosa.

Although faunal variation is more common during the burrowing episodes, its magnitude in these intervals is no greater than in nonburrowed intervals. However, the fact that two indices, Benthic Number and echinoid remains, both peak before the two burrowing episodes, then drop off to minima during the burrowing, may indicate that the sediment could support a larger epifaunal population, but later became useful to the infauna represented by the burrowers and the agglutinated foraminifers, many of which are thought to live submerged in the sediment. The fact that cibicidids behave inversely, and decrease in the levels supporting the larger populations, suggests that this genus is inhibited by some characteristic of the sediment/water interface at these times.

\section{CONCLUSIONS}

Benthic foraminifers have been analyzed from the five sites drilled on DSDP Leg 74. Census data were derived
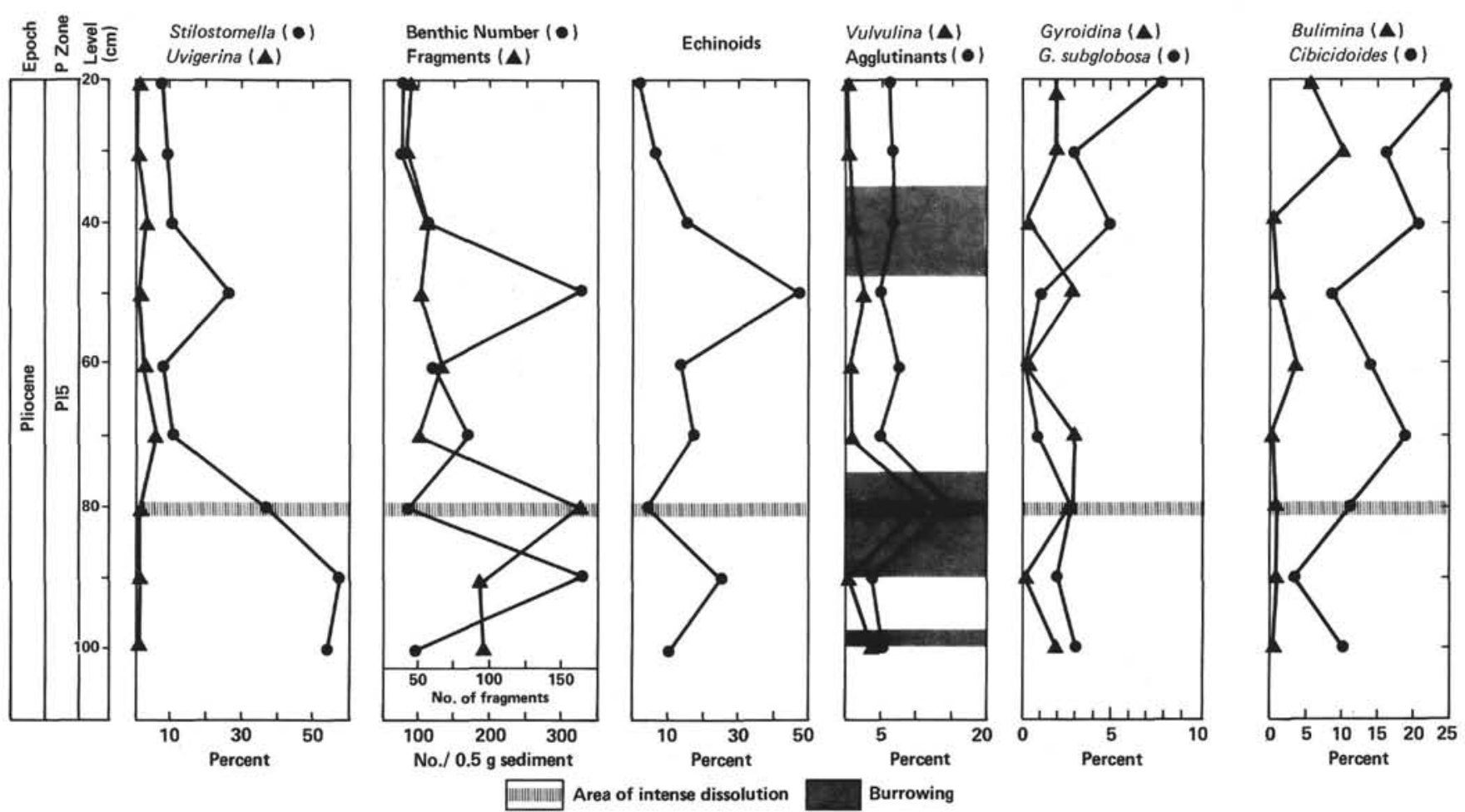

Figure 16. Variations in benthic foraminiferal abundances, numbers of fragments and echnoid remains through Core 525A-12-3 during a burrowing cycle in the lower Miocene. Species of the genera Stilostomella, Uvigerina, Gyroidina, Bulimina, and Cibicidoides were combined for these plots. All agglutinated species were combined and plotted. The number of fragments in counts of 350 grains in the $>149 \mu \mathrm{m}$ fraction were plotted. Burrowing was indicated by characteristic sediment color changes, disturbance of lineations, and wavy features. Samples were zoned according to the zonation of Berggren (1972). 
from the $<355 \mu \mathrm{m},>149 \mu \mathrm{m}$ fraction for the Paleocene and for the Oligocene through the Pliocene. Faunas were picked and counted through the Oligocene sections at Sites 526 and 529 and the Pliocene sections at Sites 525 and 527. In one Miocene-age core from Hole $525 \mathrm{~A}$, benthics and other invertebrates were picked and counted at $10 \mathrm{~cm}$ intervals through several episodes of burrowing.

Analysis of Paleocene benthic foraminifers from Site 525 , with a paleodepth near $1400 \mathrm{~m}$, and Site 527, with a paleodepth near $3200 \mathrm{~m}$, provided the following results:

1) Eleven species of benthic foraminifers with Midway affinities were present only at the shallower site 525; 10 species, including the new genus Abyssamina, were restricted to the deeper Site 527 .

2) Most appearances or disappearances at these sites are considered to be ecologically controlled, except those which occur at the Paleocene/Eocene boundary (i.e., the extinction of Gavelinella beccariformis, and the first appearances of Tappanina selmensis and Globocassidulina subglobosa).

3) Zone P4 is a time of large faunal overturn at Site 525 , involving the disappearance of 18 species, and the appearance of 11 new forms.

4) At all sites the Paleocene/Eocene boundary is characterized by the disappearance of benthic species (21 at Site 527 alone); by the origination of $T$. selmensis, the extinction of Gavelinella beccariformis, and a decrease in the size of benthic individuals. There is a greater offset between the appearance of $T$. selmensis and the disappearance of $G$. beccariformis at the deeper site; faunal changes are also diachronous relative to a carbon isotope excursion, the fauna changing later than the isotopes at the shallower site.

Although the Eocene was not studied, the Eocene/ Oligocene boundary and the Oligocene were analyzed in detail at Site 526, with a paleodepth near $600 \mathrm{~m}$; at Site 529 with paleodepth near $2800 \mathrm{~m}$; at Site 525 , with a paleodepth near $2200 \mathrm{~m}$ and at Site 363, from Leg 40, with a paleodepth near $1800 \mathrm{~m}$. The following results were drawn:

1) The Eocene/Oligocene boundary is nearly complete at Site 529; it is marked by several short dissolution pulses in Zone P17 and a number of appearances of new species including Nuttallides umbonifera, several cibicidids and buliminds, Uvigerina spinicostata, Vulvulina spinosa, and Robulus ex gr. occidentalis.

2) Twelve species are restricted to the shallowest Site 526, including uvigerinids typical of the upper Eocene of Cuba and, in the upper Oligocene, flat and attached cibicidids. The buliminids dominate the 9 species restricted to the deeper Site 529, including also Nuttallides umbonifera, elongate cassidulinids, and spinocostata uvigerinids.

3) Oligocene diversity and the Benthic Number are consistently higher at the shallower Site 526, lower at Sites 525 and 363 , and lowest at the deepest Site 529. Species abundances also grade with depth: costate buliminids tend to be more abundant at the shallower sites, whereas reticulate forms such as $B$. jarvisi are more common at the deeper site, as are the long-ranging, cosmopolitan deep sea taxa such as Oridorsalis umbonatus, Globocassidulina subglobosa, and Buliminella grata. Hispidocostate uvigerinids of the $U$. havanensis- $U$. spinicostata group predominate at the intermediate sites and decrease in import with depth, but do not occur in the $600-800 \mathrm{~m}$ paleodepth range.

4) Major faunal overturn occurs in Zone P21, particularly at the deepest Site 529, and involves the elimination of 11 species and a large drop in benthic diversity and in the abundances of benthics in general. Attached cibicidids first appear at the shallowest Site 526 at this time, and $U$. pygmaea first evolves at both sites at the top of this zone.

5) Comparison of Oligocene paleodepth estimates of Site 526 based on uvigerinid faunas with the backtrack curve for the site corroborate the utility of the uvigerinids for estimating the paleodepths in the open ocean, at least in the $200-800 \mathrm{~m}$ depth ranges.

Miocene benthic foraminifers were studied at Sites 526, with a paleodepth near $1000 \mathrm{~m}$, and at Site 525 , with a paleodepth near $2450 \mathrm{~m}$. In Core 525A-12, benthic foraminifers and other invertebrates were counted at $10 \mathrm{~cm}$ intervals. These analyses demonstrated that:

1) At the shallower Site 526 there is a major decrease in benthic foraminiferal abundance (the Benthic Number) in the lower Miocene; at this time diversity decreases and strongly keeled robulinids and the heavily ridged agglutinant Textularia mexicana appear. Faunas deriving from and typical of the Oligocene at this site recur episodically through the Miocene and at its top in Zone N17.

2) Cibicides wuellerstorfi first appears in Zone N9 at Site 526; however, during the time of major faunal overturn in Zones N12-N13, typical long-ranging Neogene species such as Pleurostomella alternans and Bulimina striata mexicana originated and Sphaeroidina bulloides disappeared. Along with the faunal overturn in N12-N13, there is a strong trend to rectilinear species typical of the Miocene of the Dominican Republic.

3) A second episode of faunal change near the top of Zone N17 involves the reappearance of the Oligocene-type fauna, including Uvigerina spinulosa, and the abundant appearance of rugose cibicidids and heavily limbate planulinids. The first appearance of the rugose cibicids is diachronous through depth; these forms first appear at the deeper Site 525 in Zone N15.

4) Comparison of changes in microfossil populations with burrowing episodes during the Miocene at Site 525 demonstrates that prior to the burrowing episode a large number of invertebrate epifauna inhabit the sediment; this environment is not preferred by cibicidids. During the burrowing episodes involving dissolution and increased fragmentation of carbonates, there is a large increase in the numbers of agglutinated species, suggesting that they are infaunal organisms and flourish in the sediments preferred or produced by the burrower.

Pliocene benthic foraminifers were counted at Site 525 , with a paleodepth near $2450 \mathrm{~m}$, and at Site 527, with a paleodepth near $4000 \mathrm{~m}$. This is the first really deep site included in this study; conclusions are:

1) Diversity and the Benthic Number are higher at the shallower Site 525. The abundance of both Nuttallides umbonifera and procellaneous benthics is generally higher at the deep Site 527. 
2) There is a major change in benthic faunas in the upper Pliocene Zones Pl5-Pl6 where the Benthic Number becomes equivalent between the two sites; the percentages of $N$. umbonifera are nearly equal at the two sites because of a large increase in their numbers at Site 525 and a decrease at Site 527 that accompanies a decrease in dissolution; at the latter deeper site, the porcellaneous species increase markedly in import.

3) During the mid Pliocene Zone $\mathrm{Pl} 3$ there is a major decrease in the Benthic Number at the deep Site 527 and an increase at the shallower Site 525. Little faunal change accompanies these variations in benthic abundance.

4) Comparison of benthic specific abundances in the fractions $>355 \mu \mathrm{m}$ and $<355 \mu \mathrm{m}$ of all samples demonstrates that there is little agreement between these two fractions.

\section{ACKNOWLEDGMENTS}

The author would like to thank Dr. Yves Lancelot and the Deep Sea Drilling Project for kindly permitting her to participate on Leg 74. Dr. I. Premoli Silva kindly arranged for the scanning photography of the Leg 74 benthics. Dr. L. Tjalsma helped with identification of Paleocene benthic species. The author is very grateful to these colleagues.

This research was conducted under a subcontract from Woods Hole Oceanographic Institution arranged by Dr. W. A. Berggren as part of the Bathyal Benthic Foraminifera project. The author is very grateful to Dr. Berggren for his support.

\section{REFERENCES}

Berggren, W., 1972. Cenozoic time-scale: some implications for regional geology and paleobiogeography. Lethaia, 5:195-215.

1973. A Pliocene time-sale: Calibrations of planktonic foraminifera and calcareous nannofossil zones. Nature, 243:391-397.

Boersma, A., 1974. Spatial and temporal distribution of species of the genus Uvigerina in the Tertiary [Ph.D. dissert.]. Brown University, Providence.

Cushman, J. A., 1951. Paleocene Foraminifers of the Gulf Coastal Region of the United States and Adjacent Areas. U.S. Geol. Surv., Prof. Pap. 232.

Hardenbol, J., and Berggren, W., 1978. A new Paleogene numerical time-scale. In Cohee, G. V., Glaessner, M. F., and Hedberg, H. D. (Eds.), Contributions to the Geologic Time Scale. Am. Assoc. Pet. Geol., Stud. Geol., 6:213-234.

Manivit, H., in press. Paleogene and Upper Cretaceous calcareous nannofossils from Deep Sea Drilling Project Leg 74. In Moore, T. C., Jr., Rabinowitz, P. D., et al., Init. Repts. DSDP, 74: Washington (U.S. Govt. Printing Office), 475-500.

Shackleton, N. J., and Hall, M. A., in press. Carbon isotope data from Leg 74 sediments. In Moore, T. C., Jr., Rabinowitz, P. D., et al., Init. Repts. DSDP, 74: Washington (U.S. Govt. Printing Office), 613-620.

Shackleton, N. J., Hall, M. A., and Boersma, A., in press. Oxygen and carbon isotope data from Leg 74 foraminifers. In Moore, T. C., Jr., Rabinowitz, P. D., et al., Init. Repts. DSDP, 74: Washington (U.S. Govt. Printing Office), 599-612. 

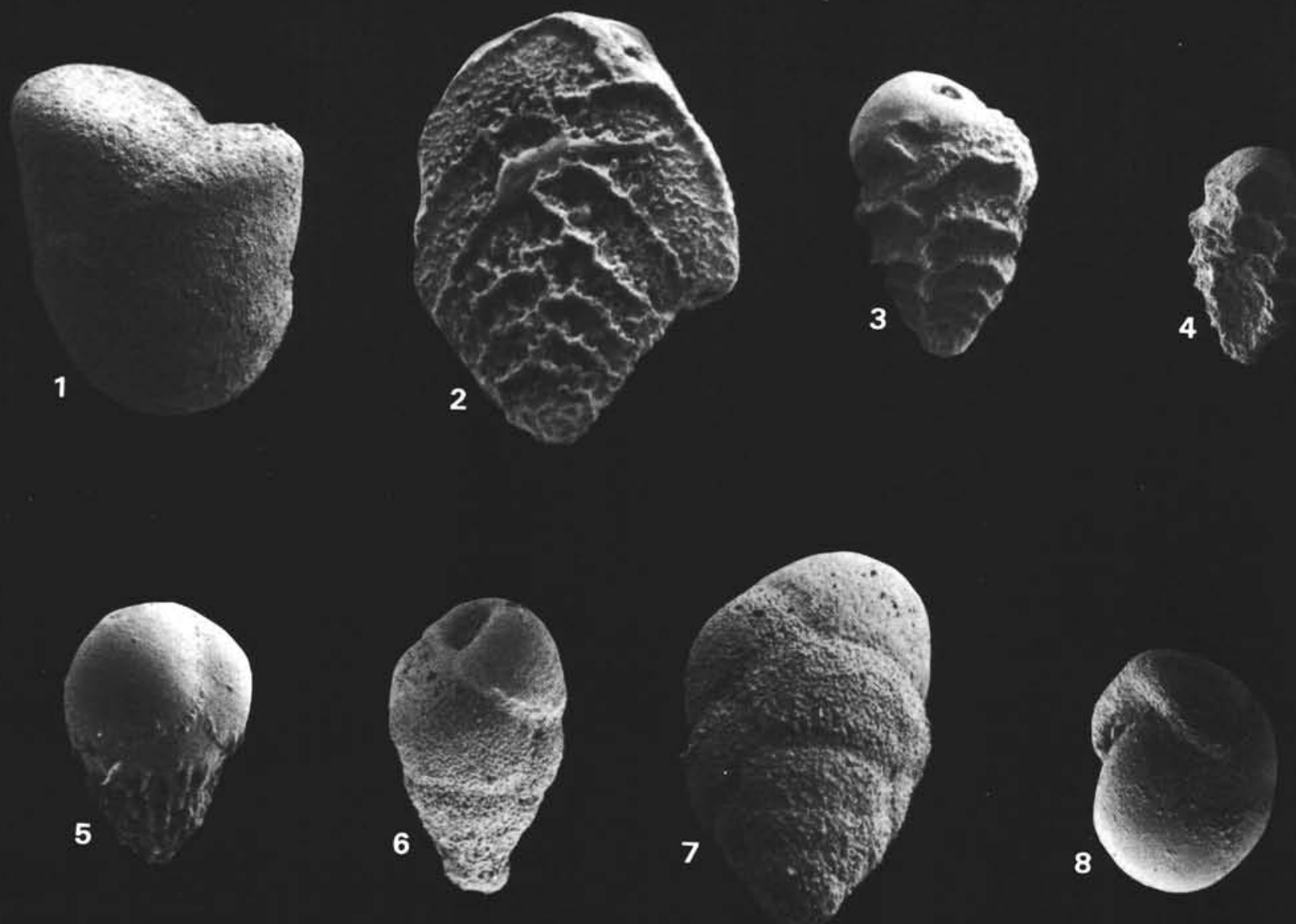

9
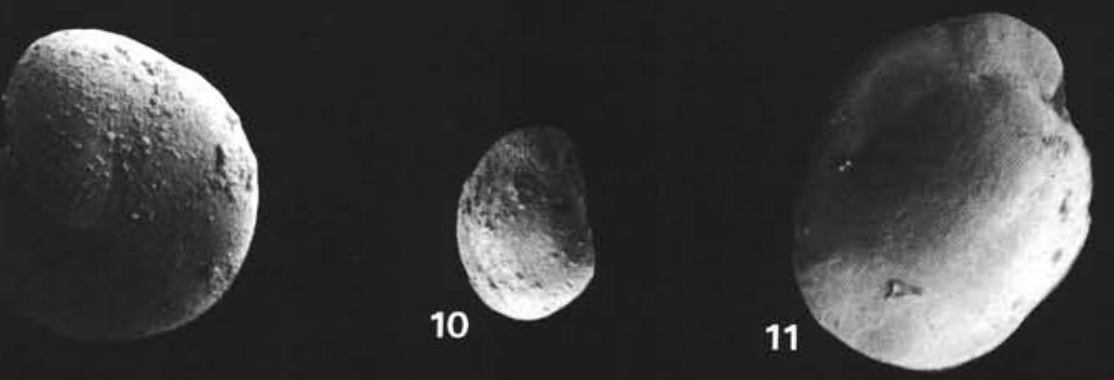

12

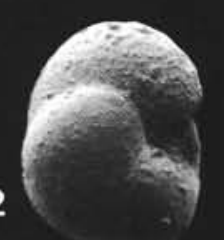

Plate 1. (All specimens $\times 110$ unless otherwise indicated. Plate photographically reduced by $25 \%$.) 1. Dorothia trochoides, Sample 528-23,CC. 2. Aragonia velascoensis, $\times 220$, Sample $528-21-5,70 \mathrm{~cm}$. 3. Tappanina selmensis, Sample $528-21-5,70 \mathrm{~cm}$. 4. Tappanina excavata, Sample $329-33-4,54 \mathrm{~cm}$. 5. Bulimina midwayensis, Sample $528,22-3,32 \mathrm{~cm}$. 6-7. Bulimina bradburyi, Sample 528-21-5, $70 \mathrm{~cm}$. 8. Clinapertina inflata, Sample 528-21-5, $70 \mathrm{~cm}$. 9. Nonion havanense, Sample 528-22,CC. 10. Alabamina creta, Sample 528-22,CC. 11. Oridorsalis umbonatus, $\times 220$, Sample $528-21-5,70 \mathrm{~cm}$. 12. Abyssamina poagi, $\times 220$, Sample $528-21-1,50 \mathrm{~cm}$. 


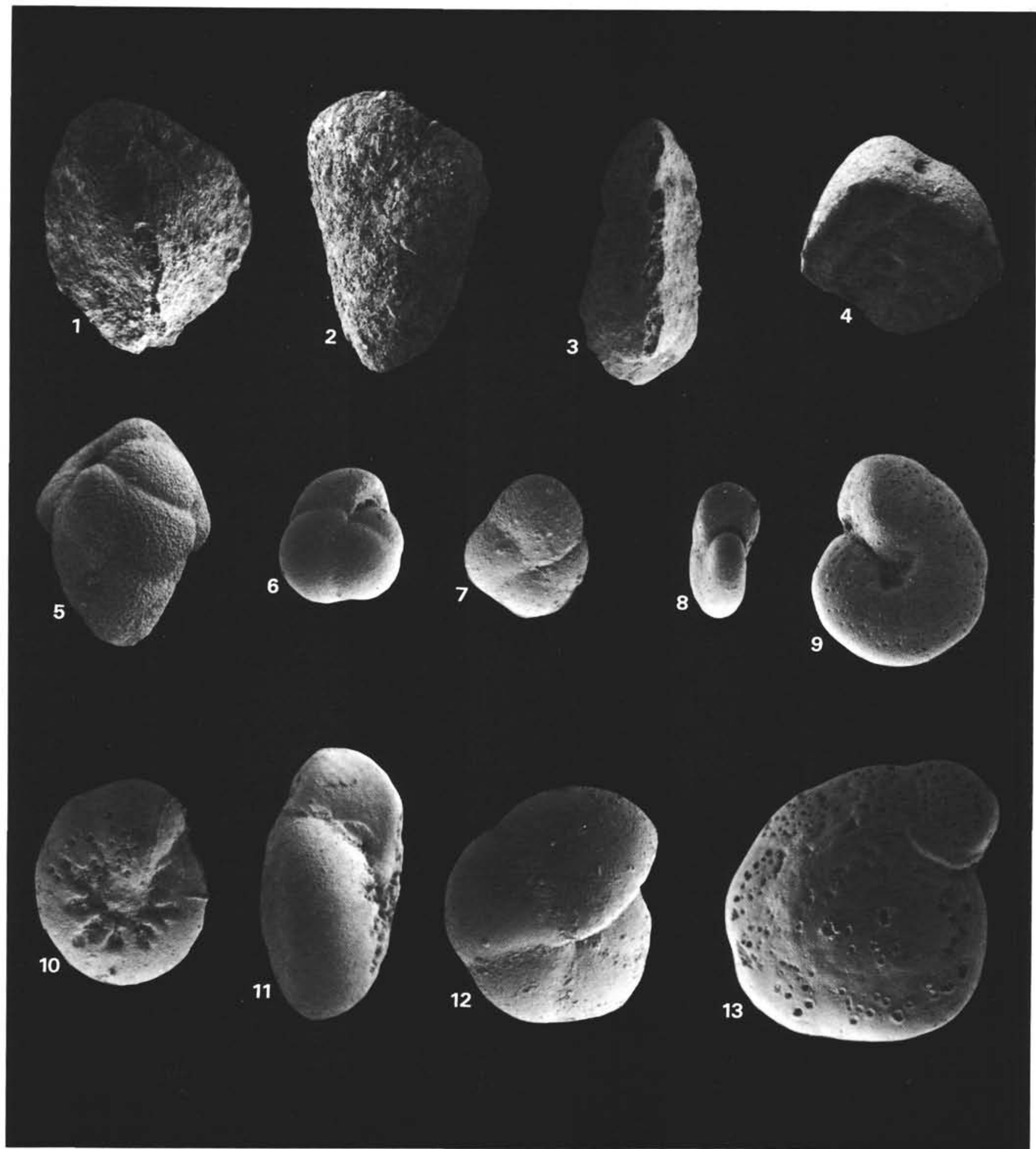

Plate 2. (All specimens $\times 110$. Plate photographically reduced by $30 \%$. Figs. 1, 3, 4, 5, 6, 11, 12, 13, Sample 525A-32,CC; figs. 2, 8, 9, Sample 525A-30,CC.) 1. Tritaxia havanensis. 2. Gaudryina laevigata. 3. Tritaxia trilatera. 4. Vulvulina spinosa. 5. Buliminella beaumonti. 6-7. Abyssamina poagi. 8, 9. Anomalinoides praeacuta. 10, 11. Gavelinella beccariformis. 12. Pullenia eocenica. 13. Cibicidoides pseudoperlucidus. 


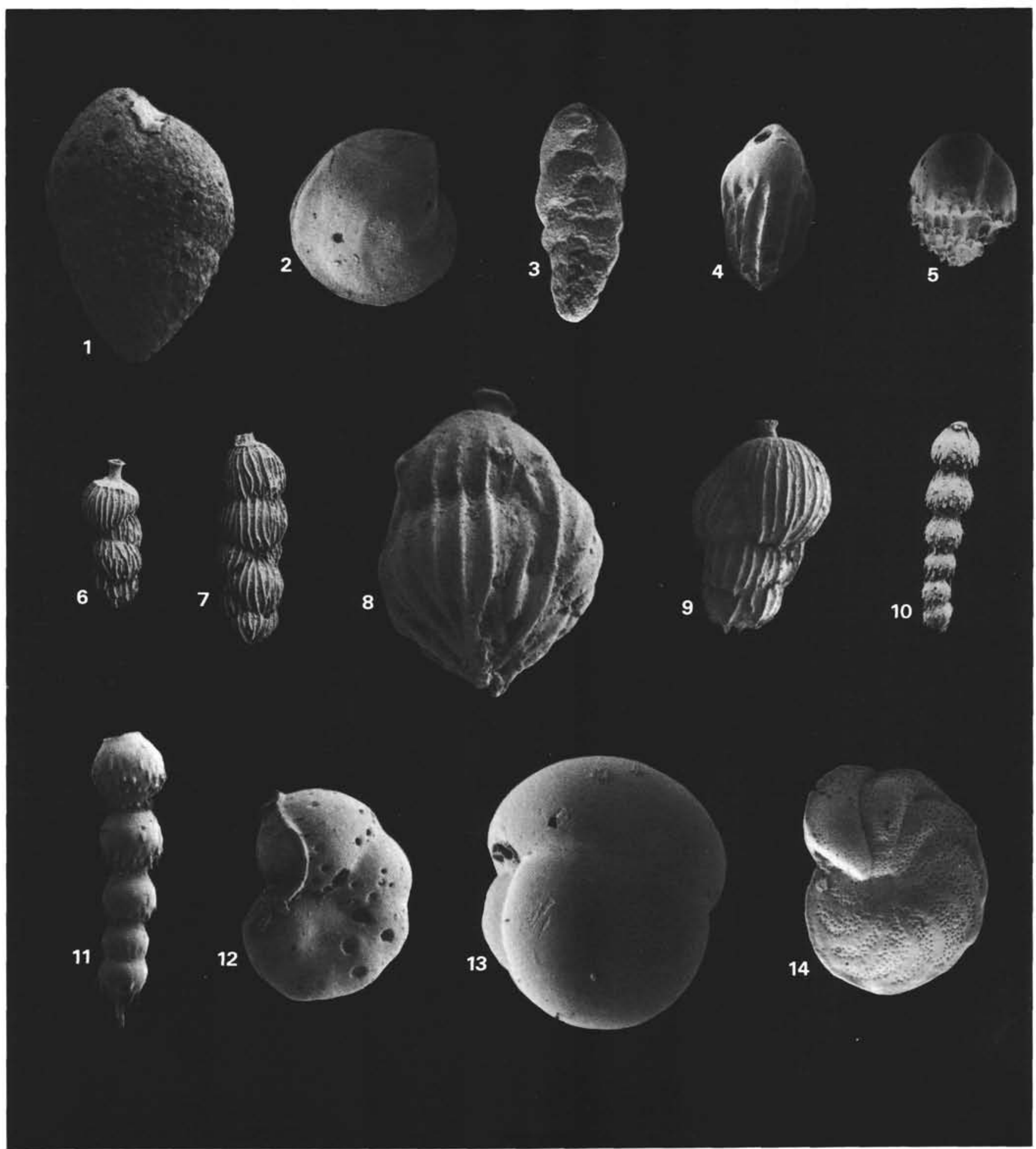

Plate 3. (All specimens $\times 110$. Plate photographically reduced by $32.5 \%$. Figs. from Sample $526 \mathrm{~A}-41-12,44 \mathrm{~cm}$ unless otherwise noted.) 1. Karreriella subglabra. 2. Robulus ex. gr. occidentalis. 3. Bolivina tortuosa. 4. Bulimina alazanensis. 5. Bulimina macilenta. 6. Rectuvigerina prisca, Sample 526A-34,CC. 7. Rectuvigerina postprandia, Sample 526A-34,CC. 8. Uvigerina semivestita. 9. Uvigerina spinulosa. Sample 526A-37-3, $70 \mathrm{~cm}$. 10, 11. Stilostomella subspinosa, Sample 526A-37-3, $70 \mathrm{~cm}$. 12. Gavelinella semicribrata. 13. Sphaeroidina bulloides, Sample 526A-41,CC. 14. Planulina renzi. 


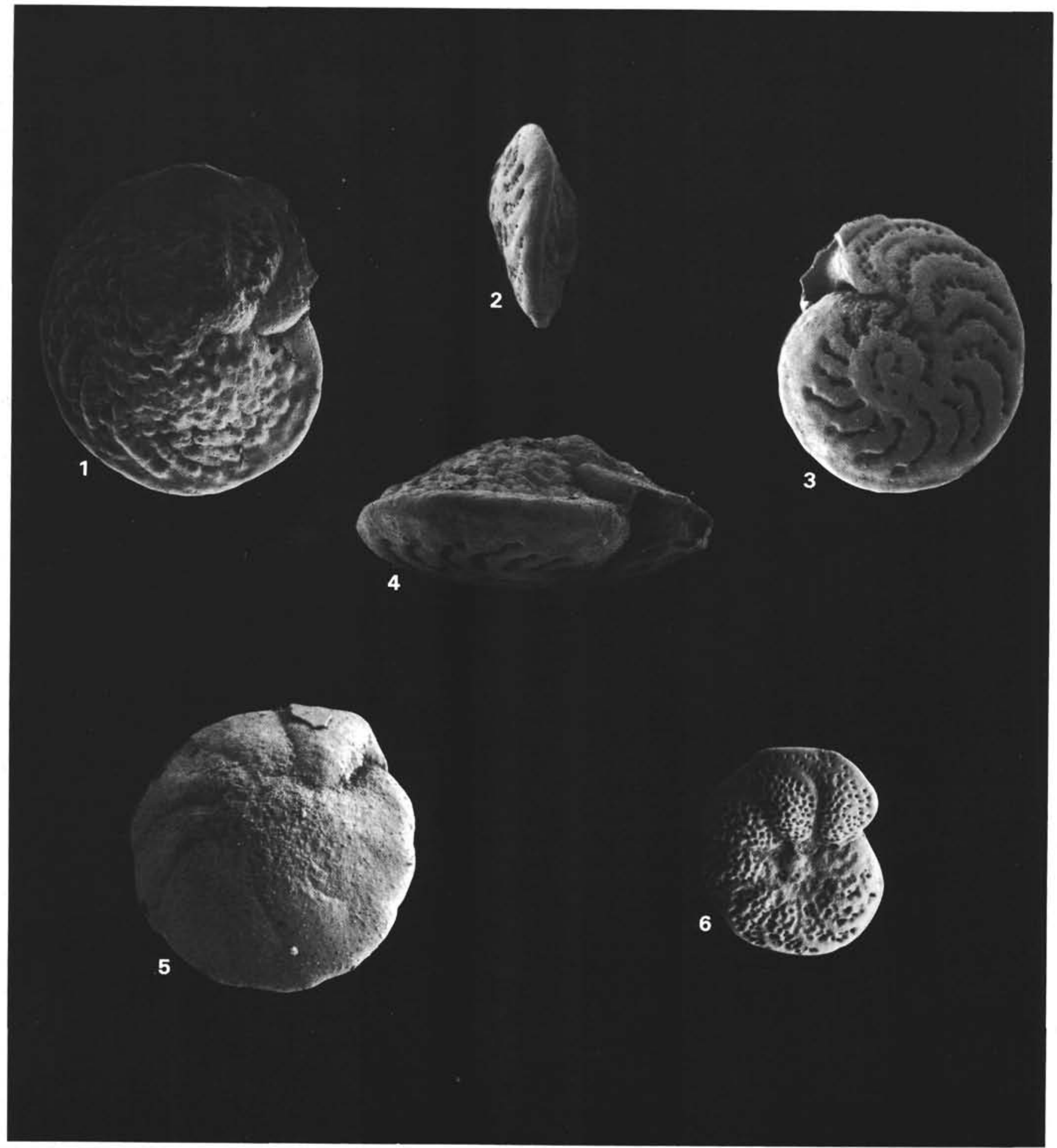

Plate 4. (Plate photographically reduced by $27.5 \%$.) 1-4. Heterolepa rugosa, $\times 55$, Sample 525B-19-2, $66 \mathrm{~cm}$. 5. Heterolepa kullenbergi, $\times 110$, Sample 525B-19-2, $66 \mathrm{~cm}$. 6. Planulina sp., $\times 110$, Sample $528-22-2,32 \mathrm{~cm}$. 


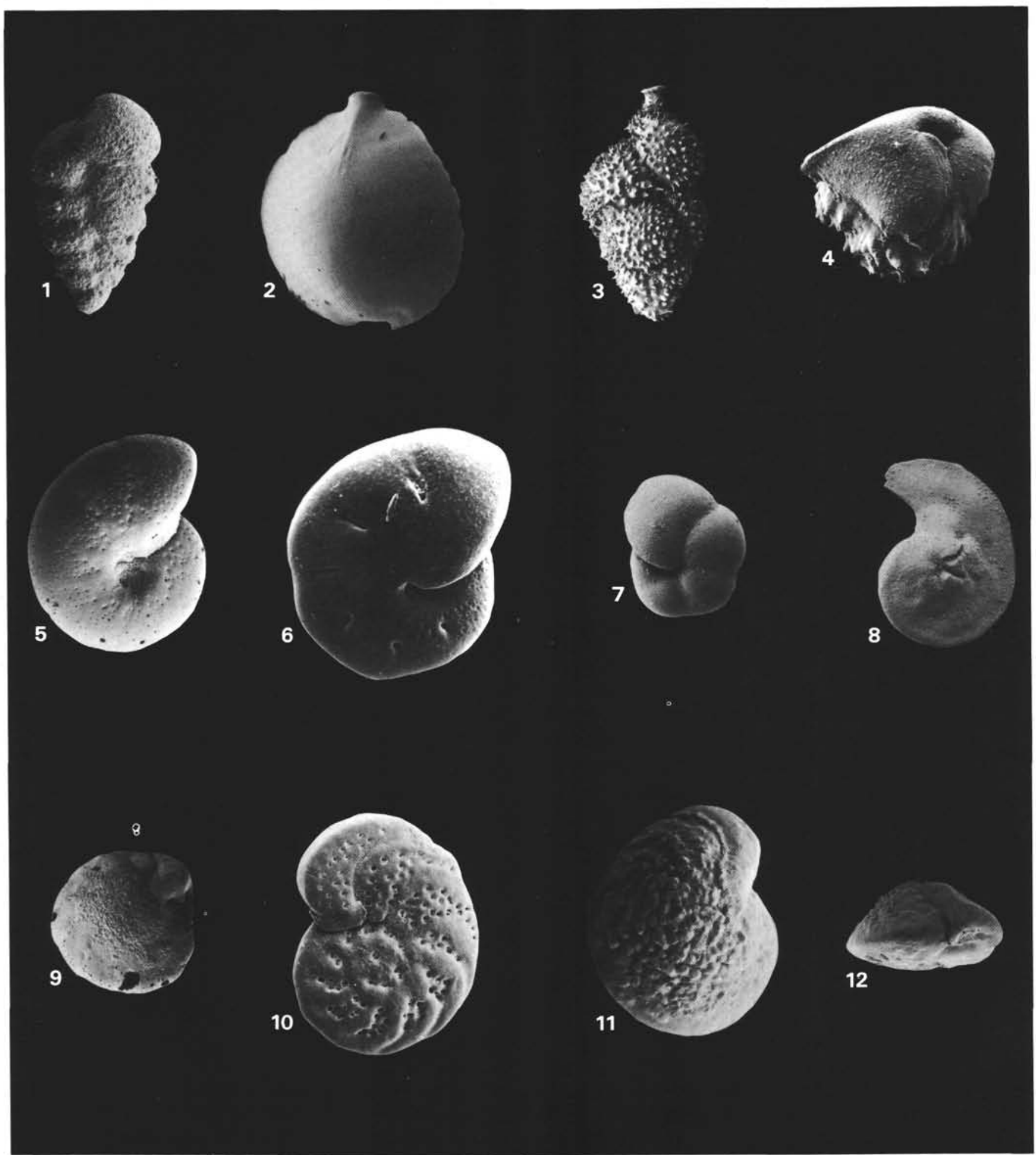

Plate 5. (Plate photographically reduced by $28 \%$.) Figs. from Sample $528 \mathrm{~A}-14-2,40 \mathrm{~cm}$ unless otherwise noted. 1. Karreriella bradyi, $\times 110$, Sample 528A-14-2, $40 \mathrm{~cm}$. 2. Pyrgo murrhina, 55, Sample $528 \mathrm{~A}-6-2,97 \mathrm{~cm}$. 3. Uvigerina hispida, $\times 110$, Sample $528 \mathrm{~A}-14-2,40 \mathrm{~cm}$. 4. Ehrenbergina spinosissima, $\times 110$, Sample $528 \mathrm{~A}-14-2,40 \mathrm{~cm}$. 5. Nonion barleanum, $\times 110$, Sample $528 \mathrm{~A}-14-2,40 \mathrm{~cm}$. 6-7. Pullenia bulloides, $\times 110$, Sample 528A-6-2, $97 \mathrm{~cm}$. 8. Laticarinina bullbrooki, $\times 55$, Sample $528 \mathrm{~A}-14-2,40 \mathrm{~cm}$. 9. Nuttallides umbonifera, $\times 110$, Sample $528 \mathrm{~A}-14-2,40 \mathrm{~cm}$. 10. Planulina cf. ariminensis, $\times 55$, Sample 528A-6-2, $97 \mathrm{~cm} .11-12$. Heterolepa rugosa, Sample 525A-14-2, 40 cm., (11), $\times 55,(12) \times 35$. 

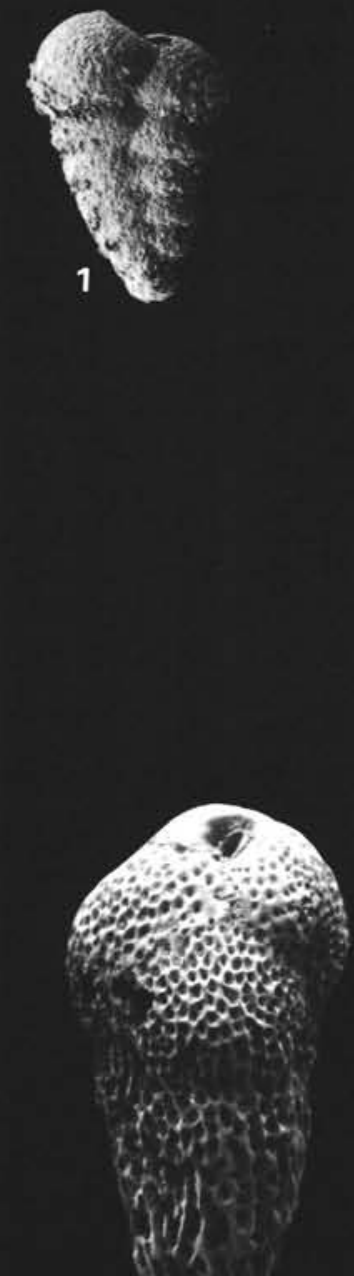

7

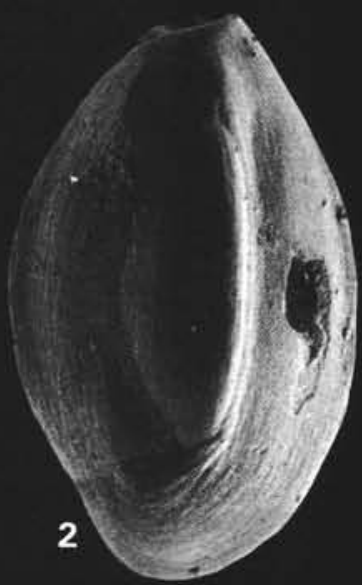

5
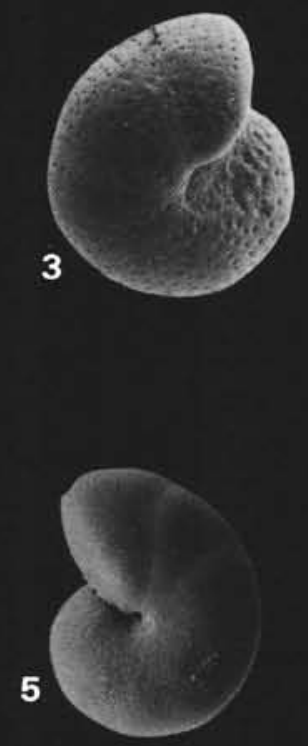

6
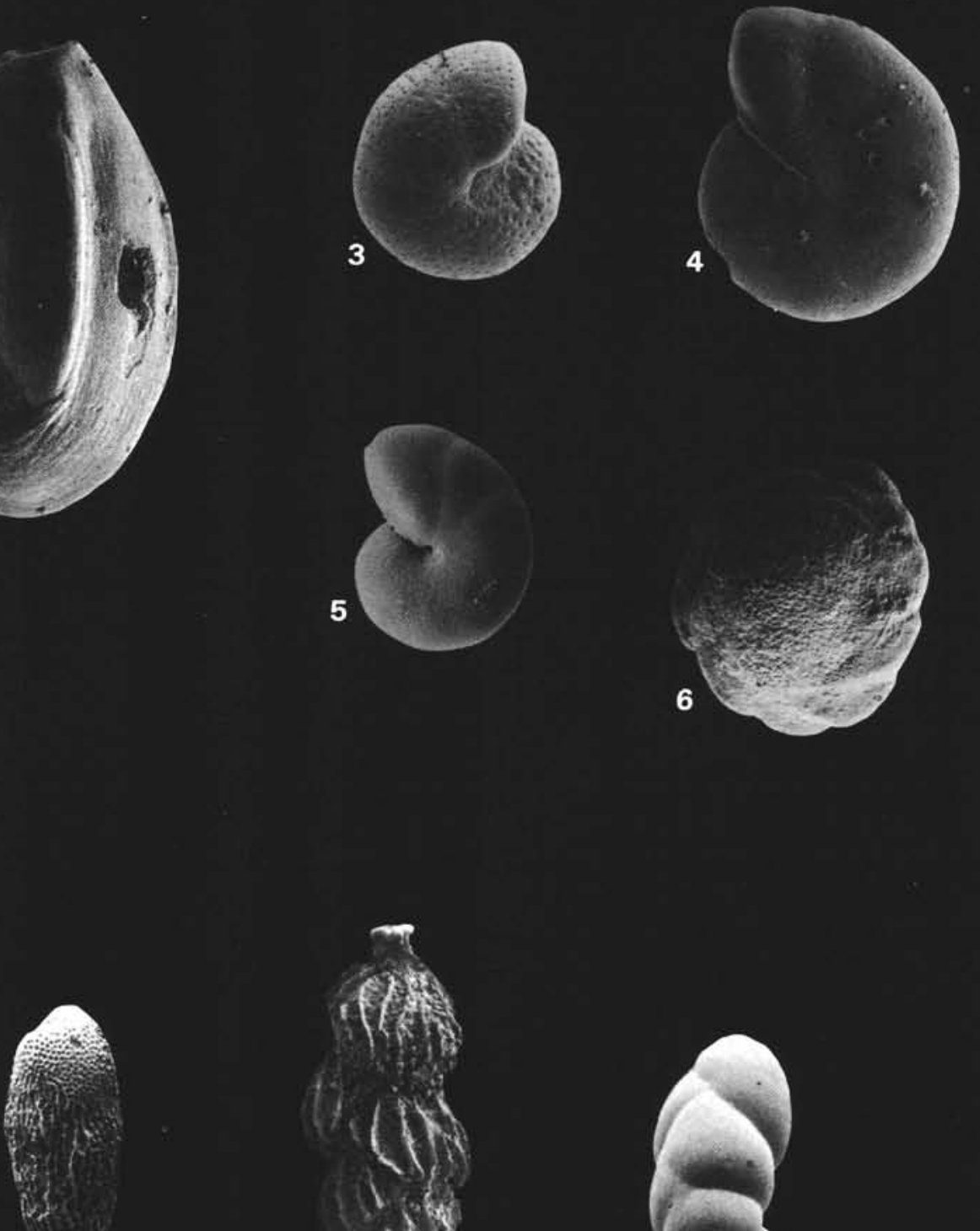

8

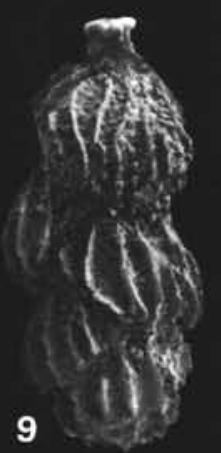

10

Plate 6. (All specimens $\times 110$. Plate photographically reduced by $29.5 \%$.) $\quad$ 1. Textularia sp. A, Sample $527-3-4,35 \mathrm{~cm} .2$. Quinqueloculina sp., Sample 527-3-4, $35 \mathrm{~cm}$. 3-5. Nonion barleanum, Sample 527-8-3, $64 \mathrm{~cm}$. 6. Nuttallides umbonifera, Sample 527-8-3, 64 cm. 7, Bulimina semicostata, Sample 529-20,CC. 8. Bulimina jarvisi, Sample 529-20,CC. 9. Uvigerina havanensis, Sample 529-20,CC. 10. Cassidulinoides bradyi, Sample 529-6-2, $44 \mathrm{~cm}$. 


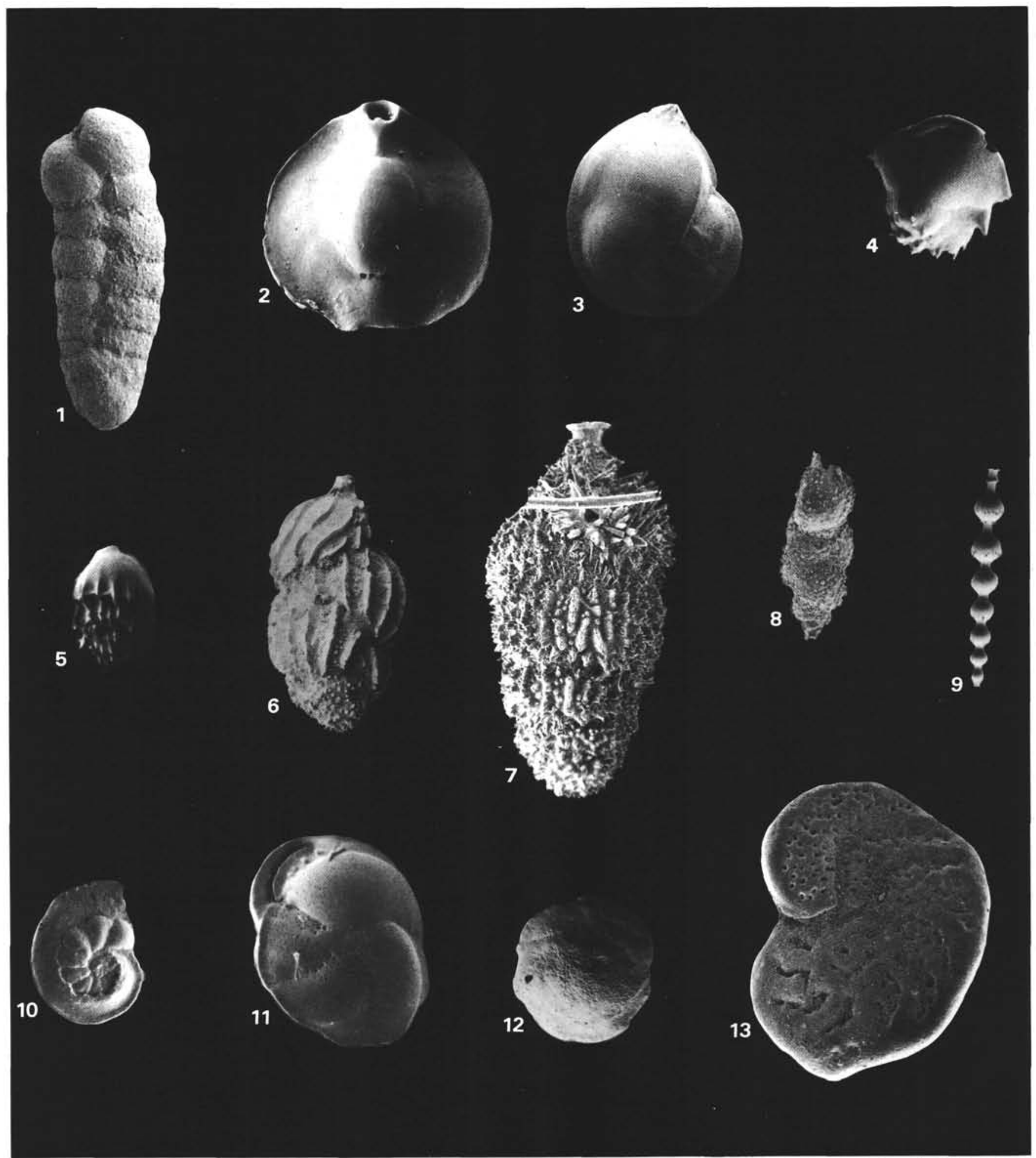

Plate 7. (All specimens $\times 110$ unless otherwise indicated. Plate photographically reduced by $30 \%$. Figs. 1, 5, 8, 10, 11, 13, Sample 525B-11,CC; Figs $2,3,4,6,9,12$, Sample $525 \mathrm{~B}-3-3,33 \mathrm{~cm} \mathrm{1.} \mathrm{Karreriella} \mathrm{subrotundata,} \times 55.2$. Pyrgo murrhina. 3. Robulus cf. cultratus, $\times 55$. 4. Ehrenbergina spinossissima. 5. Bulimina striata mexicana, $\times 55$. 6. Uvigerina peregrina, 7. Uvigerina hispido-costata, Sample $525 \mathrm{~B}, 12, \mathrm{CC}$. 8. Uvigerina auberiana. 9. Stilostomella lepidula, $\times 55$. 10. Laticarinina halophora, $\times 22 . \quad 11$. Cassidulina laevigata. 12 . Nuttallides umbonifera. 13. Planulina cf. ariminensis. 


\section{A. BOERSMA}

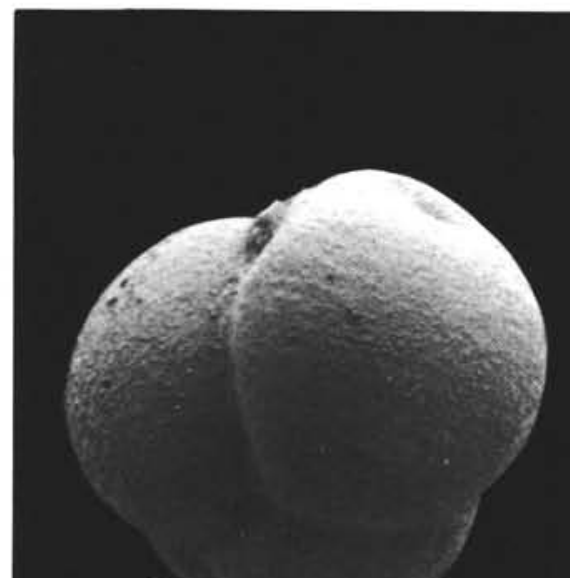

1

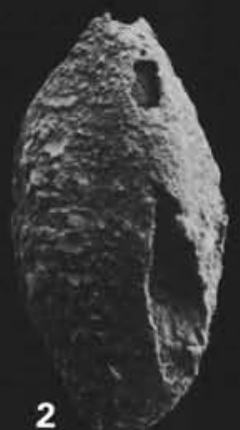

2
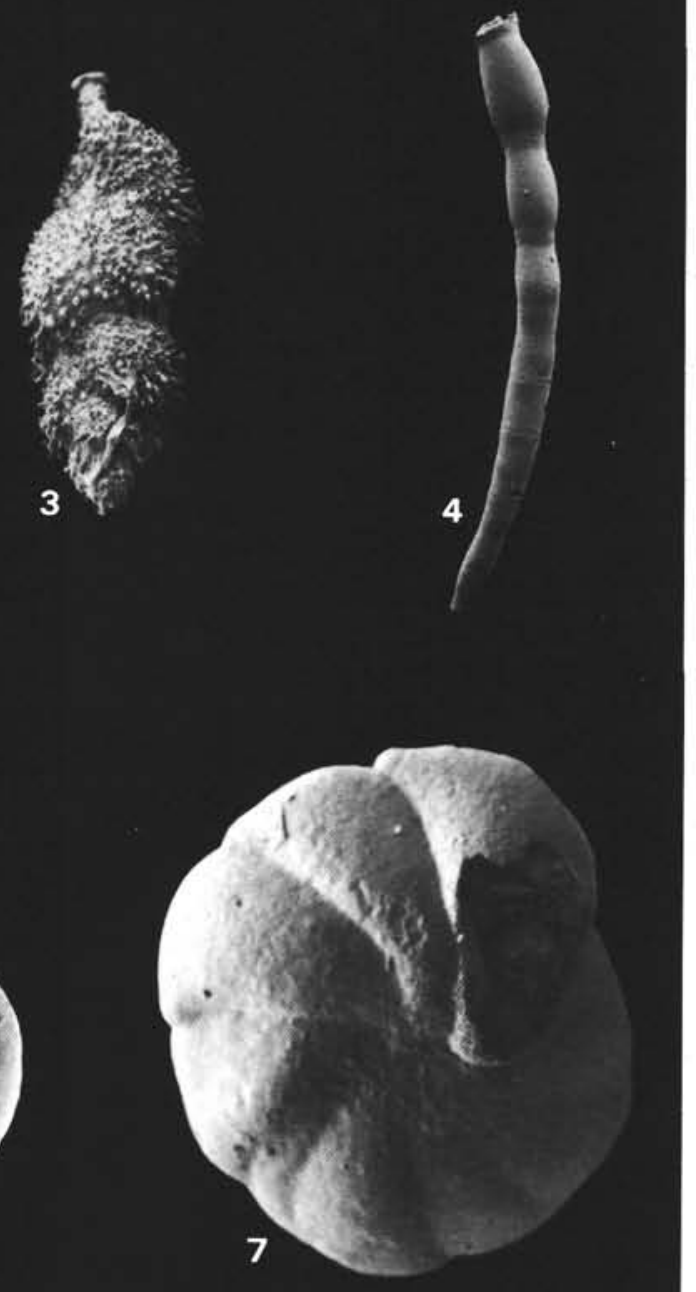

6
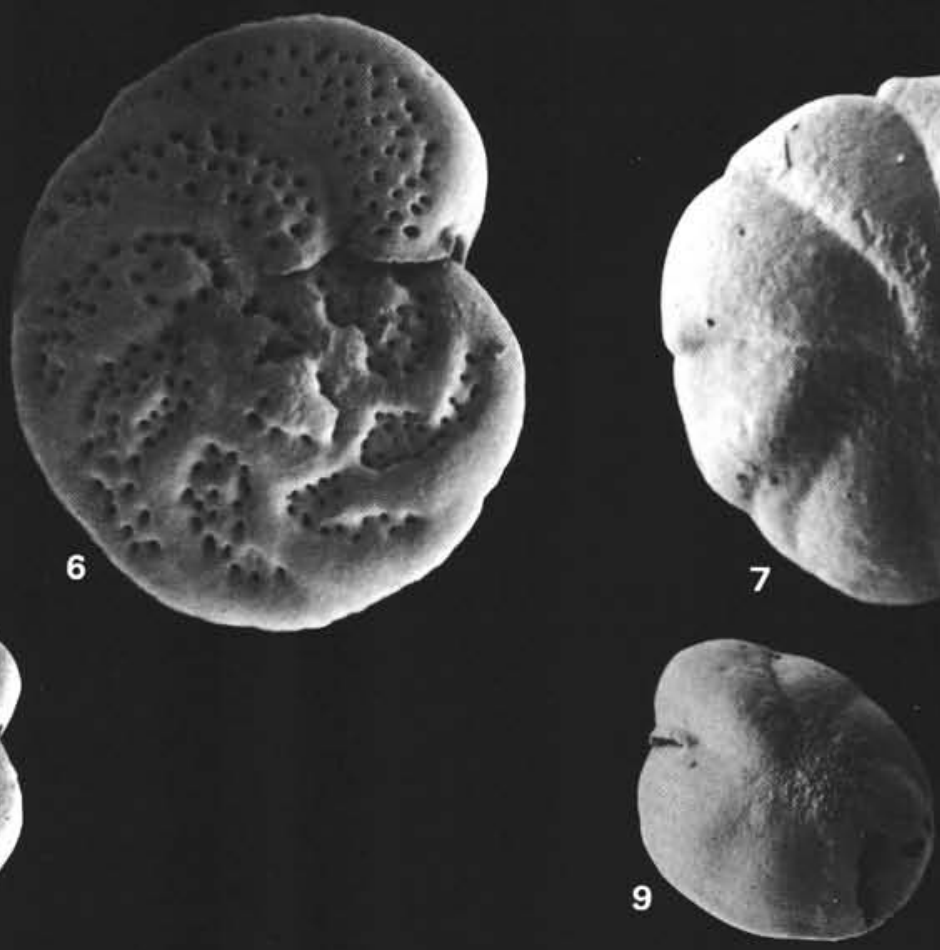

Plate 8. (All specimens $\times 110$. Plate photographically reduced by $30.5 \%$. Figs. 1, 5, 7, 8, 9, Sample 526A-11,CC; Figs. 2, 3, 4, 6, Sample 526A-4,CC.) 1. Eggerella bradyi. 2. Sigmoilopsis schlumbergeri. 3. Uvigerina proboscidea. 4. Chrysalogonium lanceolum. 5. Globocassidulina subglobosa. 6. Planulina cf. ariminensis. 7,9. Heterolepa kullenbergi. 8. Pullenia quinqueloba. 